Photograph taken by Robin Tausch 


\section{Piñon and Juniper Field Guide: Asking the Right Questions to Select Appropriate Management Actions}

By R.J. Tausch, U.S. Forest Service Rocky Mountain Research Station, R.F. Miller, Oregon State University, B.A. Roundy, Brigham Young University, and J.C. Chambers, U.S. Forest Service Rocky Mountain Research Station

This is contribution number 02 of the Sagebrush Steppe Treatment Evaluation Project (SageSTEP), supported by funds from the U.S. Joint Fire Science Program. Partial support for this guide was provided by the U.S. Geological Survey Forest and Rangeland Ecosystem Science Center.

Circular 1335

U.S. Department of the Interior U.S. Geological Survey 


\section{U.S. Department of the Interior KEN SALAZAR, Secretary}

\section{U.S. Geological Survey Suzette M. Kimball, Acting Director}

\section{U.S. Geological Survey, Reston, Virginia: 2009}

For more information on the USGS - the Federal source for science about the Earth, its natural and living resources, natural hazards, and the environment, visit http://www.usgs.gov or call 1-888-ASK-USGS

For an overview of USGS information products, including maps, imagery, and publications, visit http://www.usgs.gov/pubprod

To order this and other USGS information products, visit http://store.usgs.gov

Any use of trade, product, or firm names is for descriptive purposes only and does not imply endorsement by the U.S. Government.

Although this report is in the public domain, permission must be secured from the individual copyright owners to reproduce any copyrighted materials contained within this report.

Suggested citation:

Tausch, R.J., Miller, R.F., Roundy, B.A., and Chambers, J.C., 2009, Piñon and juniper field guide: Asking the right questions to select appropriate management actions: U.S. Geological Survey Circular 1335, 96 p.

Edited and Designed by: Summer C. Olsen and Elizabeth A. Didier, Outreach Program Coordinators, Utah State University, Logan, Utah State University

All photographs in this guide were taken by Richard Miller and Robin Tausch unless otherwise noted. 


\section{Contents}

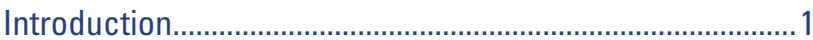

Questions to be Addressed ..................................................... 8

Setting Goals and Objectives.............................................. 12

Part I: The Ecological Site …………………………............ 14

Part II: The Current State of the Site …………………......45

Part III: Landscape Considerations .........................................67

Part IV: Selecting Appropriate Management Actions and Treatments ................................................................ 71

Appendix 1: Field Assessment Form.....................................89

Appendix 2: Species Codes..................................................

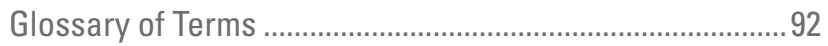




\section{Figures}

Figure 1. Piñon and juniper encroachment at upper Underdown Canyon, Shoshone Mountains, central Nevada

Figure 2. Current distribution of western juniper (Juniperus occidentalis) in the western United States

Figure 3. Current distribution of Utah juniper (Juniperus osteosperma) in the western United States

Figure 4. Current distribution of singleleaf piñon (Pinus monophylla) in the western United States

Figure 5. Current distribution of Colorado piñon (Pinus edulis) in the western United States......6

Figure 6. Phase II woodland 13

Figure 7. Ecological Provinces of the southwestern United States

Figure 8. Soil texture triangle 17

Figure 9. Mountain big sagebrush/Idaho fescue plant association with moderately deep ( $>30$ in.), well-drained, clay loam soils

Figure 10a. A shallow restrictive soil layer limits tree rooting depth resulting in a loss of shrubs, grasses, and forbs

Figure 10b. Former Wyoming big sagebrush community on a site with a restrictive soil layer similar to fig. 10a. now fully dominated by Utah juniper

Figure 11. Dead bitterbrush and big sagebrush remnants can be distinguished by differences in the wood; bitterbrush (top) is clear while sagebrush (bottom) has dark brown bands perpendicular to the annual growth rings.......21 


\section{Figures-Continued}

Figure 12. Diagnostic sagebrush community species oriented along a general warm-dry to cool-wet gradient

Figure 13. Common sagebrush species and subspecies associated with pinon-juniper woodlands.

Figure 14. Examples of the range of variation in old-growth woodland sites

Figure 15. An open old-growth Utah juniper dominated shrub savanna in east-central Nevada

Figure 16. Old-growth Utah juniper and singleleaf piñon with dead branches and missing bark

Figure 17. Bark characteristics of species of woodland trees of different ages. .40

Figure 18. Mountain big sagebrush/bluebunch wheatgrass plant association with a stand of pre-settlement Utah juniper trees growing on shallow soils.

Figure 19. Wyoming big sagebrush community with charred stumps on shallow to moderately deep soils that indicate a low density of trees has occupied the site since prior to the mid-1800s

Figure 20. Relation of time since fire and the percent composition (dominance) of grasses, shrubs, and trees

Figure 21. Phase II piñon-juniper expansion woodlands in a mountain big sagebrush community with a high level of structural diversity 


\section{Figures-Continued}

Figure 22. Leader growth, particularly for trees

$<3 \mathrm{~m}$ tall, is a good indicator of competition among trees

Figure 23. Three phases of woodland succession in piñon-juniper woodlands

Figure 24. Conceptual model with estimated time periods form initial woodland establishment (early Phase I) to minimum stocking adequate to reach Phase III with tree growth, and estimated maximum potential for relative abundance and cover for stands developing on sites from high to low productivity

Figure 25. Relation between age and tree height across a range of tree dominance on relatively productive piñon-juniper sites: tree height of dominant and co-dominant individuals more than two meters tall can be used as a coarse proxy to estimate stand age

Figure 26. Third growing season after a high-severity fire in a high-productivity Phase III expansion piñon-juniper site

Figure 27. Rapid expansion and growth of piñon-juniper has led to bare ground and dead shrub skeletons

Figure 28. This site lacks both woody and herbaceous understory to carry a fire and adequate desirable herbaceous species for restoration.

Figure 29. A Phase III Utah juniper site with large areas of bare ground potentially susceptible to accelerated runoff and erosion 


\section{Figures-Continued}

Figure 30. A piñon-juniper site with large, connected zones of bare ground and water flow patterns in the inter-canopy

Figure 31. Tree cavity in the trunk of an old-growth singleleaf piñon

Figure 32. Example of juniper resprouting after chainsaw cutting left a lower limb

Figure 33. An example of tree mastication (bullhogging) on a juniper-dominated site in western Utah.

Figure 34. Piñon-juniper chainsaw cutting in woodlands.

Figure 35. Understory responses 2 years after prescribed fire in Phases I, II, and III piñonjuniper dominated Wyoming big sagebrush communities in eastern Nevada

Figure 36. Thirty-five-year-old north-slope wildfire that burned through Phase III expansion piñon-juniper woodlands

Figure 37. Moderate-severity fire where $80 \%$ of the native species in the understory survived; no seeding is required .85

Figure 38. Examples of high-severity fire where mortality of native herbaceous species was $>80 \%$ .86 


\section{Tables}

Table 1. Morphological characteristics of postsettlement ( $<150$ years) and pre-settlement (>150 years) woodland trees

Table 2. Stand characteristics differentiating three transitional phases of woodland succession for most sagebrush associations .54

\section{Keys}

Key 1. Common sagebrush species and subspecies associated with piñon-juniper woodlands......22

Key 2. Identifying ecological site and estimated fire return interval (FRI) 


\section{Introduction}

Piñon-juniper woodlands are an important vegetation type in the Great Basin. Old-growth and open shrub savanna woodlands have been present over much of the last several hundred years. Strong evidence indicates these woodlands have experienced significant tree infilling and major expansion in their distribution since the late 1800 s by encroaching into surrounding landscapes once dominated by shrubs and herbaceous vegetation (fig. 1). Both infilling and expansion affects soil resources, plant community structure and composition, water and nutrient cycles,

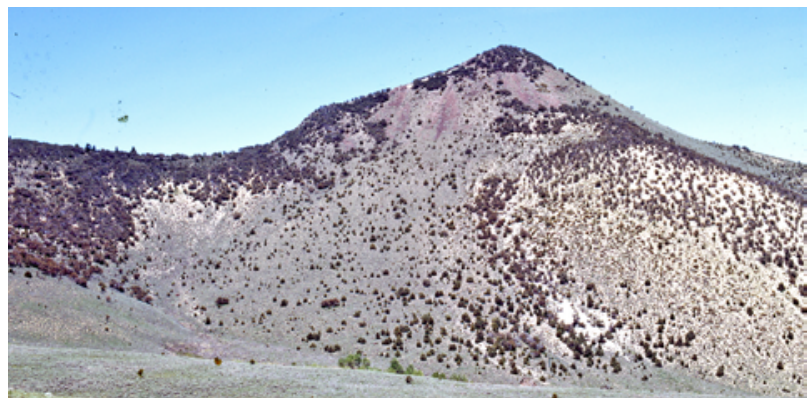

(a)

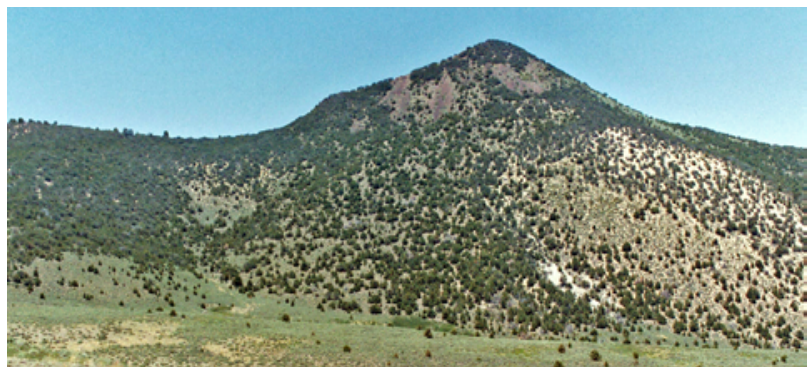

(b)

Figure 1. Piñon and juniper encroachment at upper Underdown Canyon, Shoshone Mountains, central Nevada, (a) 1973 and (b) 2007. 
forage production, wildlife habitat, biodiversity, and fire patterns across the landscape. Another impact is the shift from historic fire regimes to larger and more intense wildfires that are increasingly determining the future of this landscape.

The major goal of woodland management is to reverse these changing patterns by attempting to restore a functioning and resilient ecosystem through a more balanced plant community, which in areas of woodland expansion include a robust assemblage of grasses, forbs, and shrubs. With a robust assemblage of perennial grasses and forbs, in particular, a properly functioning ecosystem is better able to resist dominance by cheatgrass and other exotic weed species after fire or other disturbances. Even with prevention, maintenance, or restoration efforts to reduce trees by mechanical methods or prescribed fire, significant management will also be directed towards treatment following wildfire. Developing a management approach for implementing either preventive treatments or post wildfire restoration can be a difficult task. This is because of uncertainty about how the vegetation, soils, hydrologic function, and wildlife will respond to treatment.

Woodlands in the Great Basin represent a complex mix of trees, sagebrush, other shrubs, perennial and annual forbs, perennial grasses, and non-native grass and forb invaders. In different parts of the region, the distributions of four tree species overlap. These species include western juniper (fig. 2), Utah juniper (fig. 3), singleleaf piñon (fig. 4), and Colorado piñon (fig. 5). They occur alone or in mixes of two or rarely three species. The distributions of these tree species combined encompass nearly the full range of sagebrush species and subspecies, plus other shrub grass, and forb species. Responses to disturbances, such as insect outbreaks, drought and wildfire, or preventive or restoration treatment usually varies with the mix of tree, sagebrush, and perennial grass and forb dominants present on the site. 


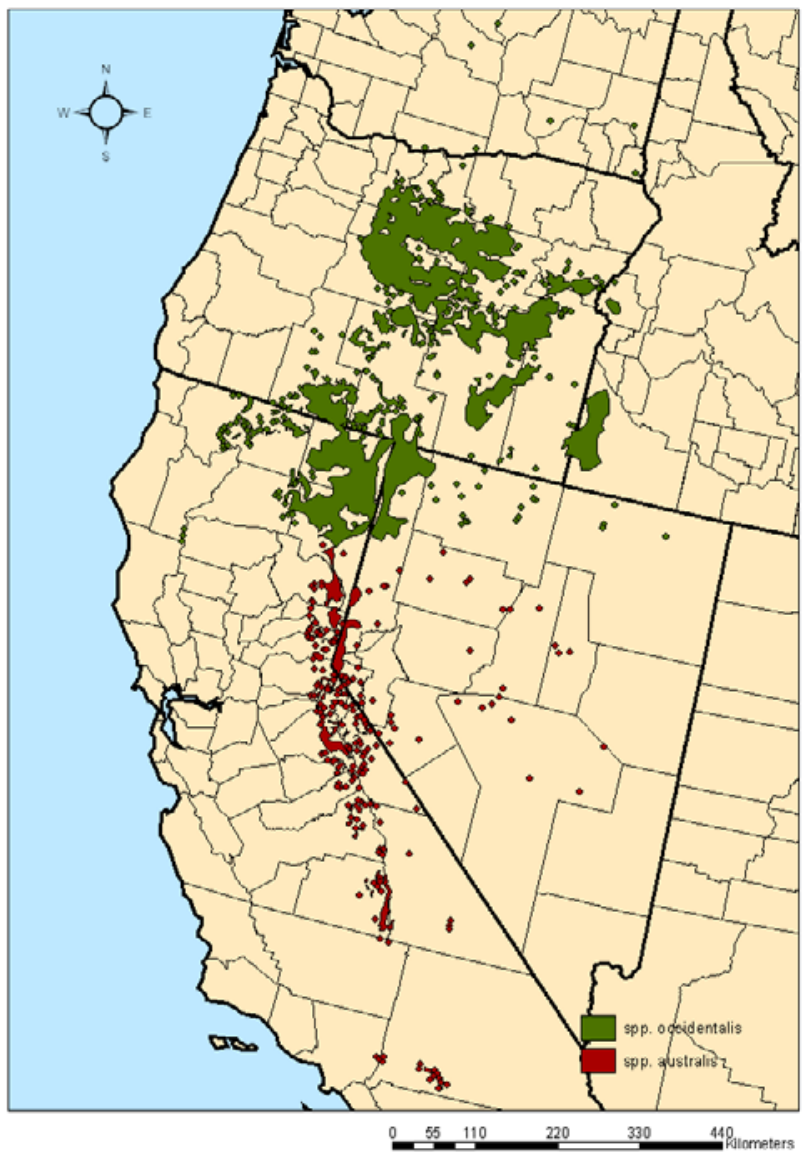

\section{릉}




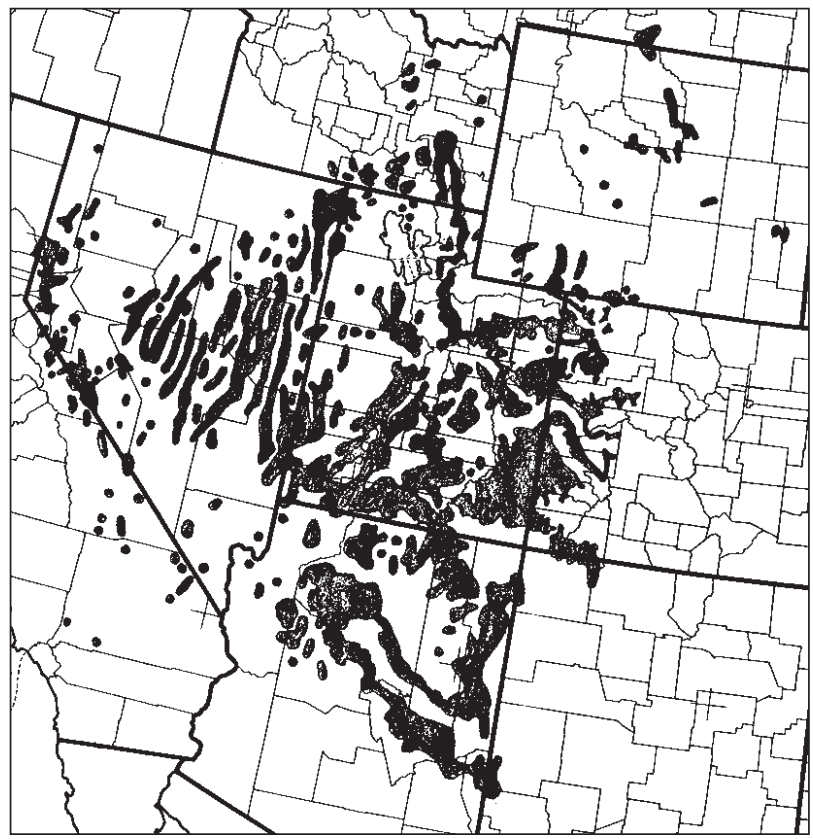

Figure 3. Current distribution of Utah juniper (Juniperus osteosperma) in the western United States (from Little, 1971).

When developing a management strategy, the first and possibly most important step towards success is asking the right questions. Identifying the attributes of the area to be treated, including the vegetation composition, soils, slope, aspect, elevation, geology, and ecological province, and then selecting the right treatments to be applied are of utmost importance. To best match long-term goals and objectives to the site, it can be beneficial to assess potential natural vegetation, soils, and the current successional and hydrologic states of the site. This allows us to best determine what components need to be restored to meet realistic objectives. In addition to the site conditions, it is equally important to determine how the management unit fits in 


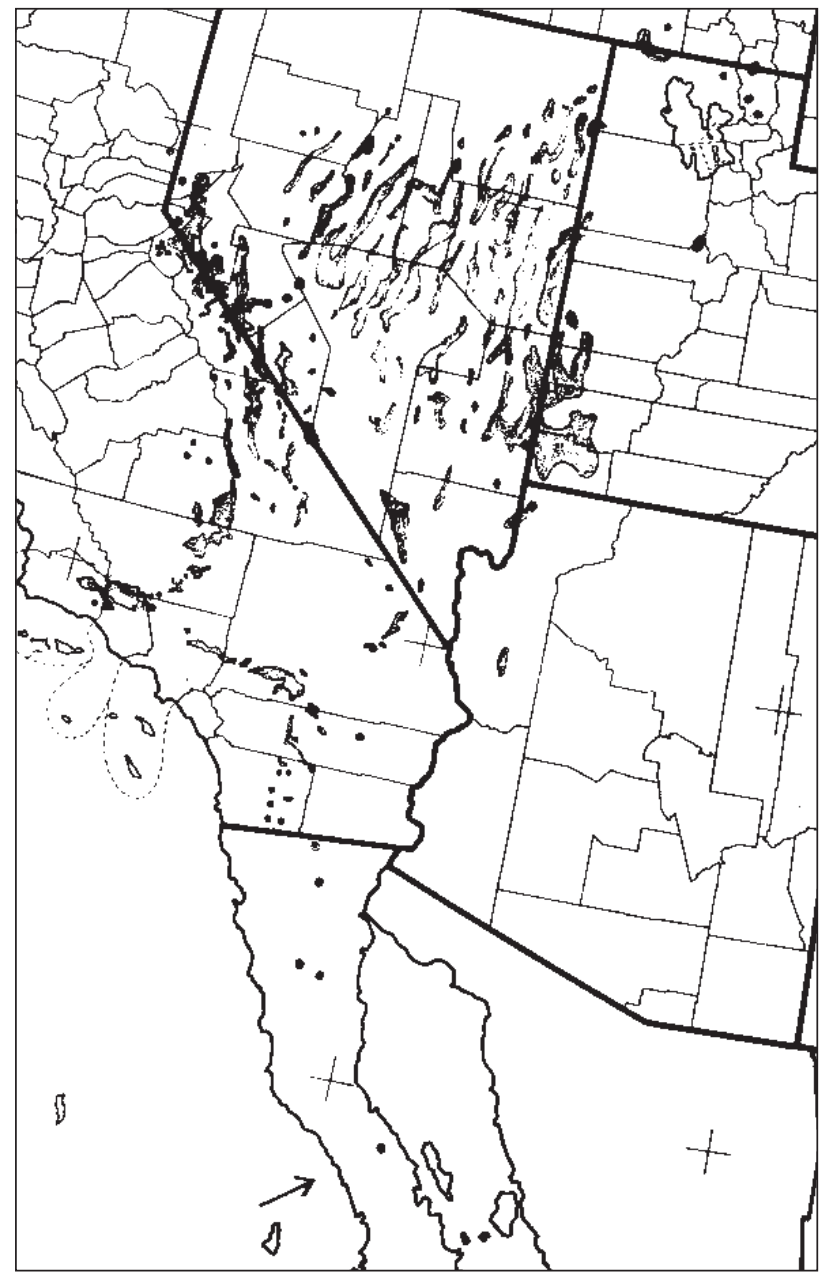

Figure 4. Current distribution of singleleaf piñon (Pinus monophylla) in the western United States (from Little, 1971). 


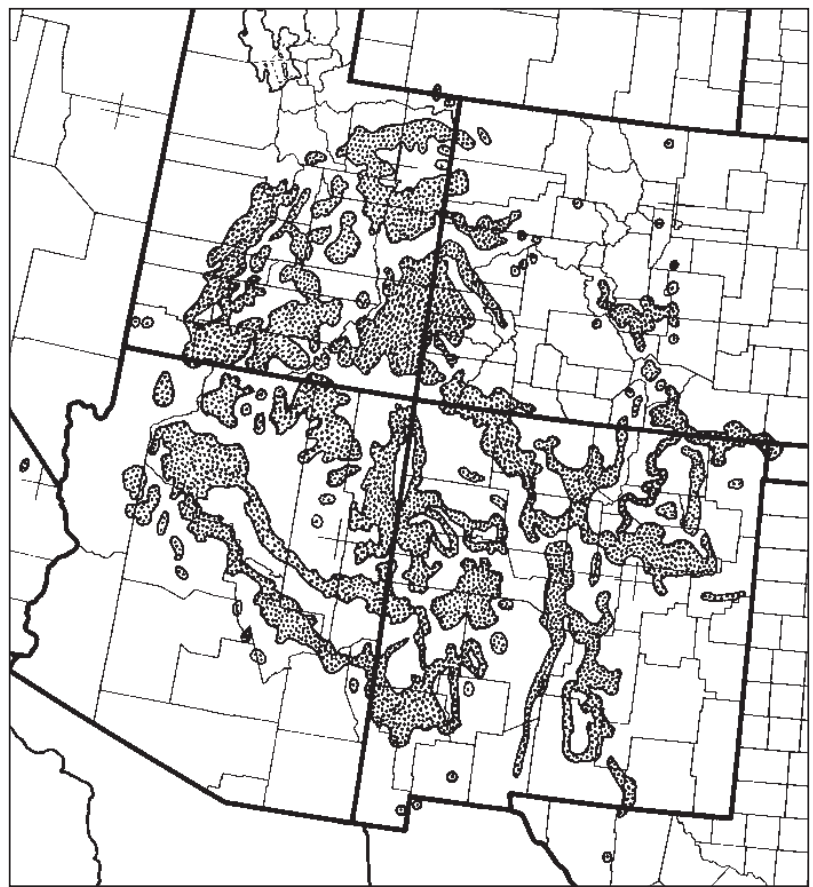

Figure 5. Current distribution of Colorado piñon (Pinus edulis) in the western United States (from Little, 1971).

the overall landscape mosaic, including the potential for wildfire. Keep in mind that sagebrush-steppe vegetation is dynamic, and management strategies will be most effective if multi-decade time frames are taken into account, particularly when piñon and juniper trees are present.

This guide provides a set of tools to help field biologists; land managers, including fuels specialists and fire managers; representatives of NGO's; and private landowners conduct rapid, qualitative field assessments that address a site's potential, current state, and relation to the surrounding landscape. These tools include a list of questions to be addressed and a series of photographs, 
keys, tables, and figures to aid in site evaluation. This assessment is designed to help prioritize sites to be treated, select the best treatment, and help predict outcomes.

Success of a piñon and juniper management program may be greatly enhanced if an interdisciplinary team of experienced local managers and resource specialists use this guide as an aid in decision-making. Knowledge of vegetation, fuels, potential fire patterns, soils, hydrology, grazing, wildlife, and their relationships to the surrounding landscape, as well as economic and sociological aspects of the local area, are essential to successful management and implementation of treatments.

\section{Supporting Literature}

This piñon-juniper guide closely corresponds to the publication Western Juniper Field Guide: Asking the Right Questions to Select Appropriate management Actions by Richard Miller and others (U.S. Geological Survey Circular 1321, 2007) (fig. 2). It also is closely linked to the synthesis publications

- Biology, Ecology, and Management of Western Juniper by Richard Miller and others (Oregon State University Agricultural Experiment Station Technical Bulletin 152, 2005);

- Age Structure and Expansion of Piñon-Juniper: A Regional Perspective in the Intermountain West by Richard Miller and others (U.S. Department of Agriculture, Forest Service, Research Paper Report RMRS-RP-069, 2008);

- Fire related restoration issues in woodlands and rangeland ecosystems by Jeanne Chambers, (Mixed Fire Regimes: Ecology and Management Symposium Proceedings, in L. Taylor, J. Zelnik, S. Ladwaller, and B. Huges (compilers), November 11-19, 2004, Spokane, WA. AFE MIXC03); 
- Piñon-Juniper Woodlands by Robin Tausch and Sharon Hood, Chapter 4 in: Fire Ecology and Management of Major Ecosystems of Southern Utah, (U.S. Department of Agriculture, Forest Service, Rocky Mountain Research Station, General Technical Report, RMRS-GTR-202, 2007); and

- Atlas of United States Trees (U.S. Department of Agriculture, Forest Service, Washington, D.C., Miscellaneous Publication No. 1146, 1971) (figs. 3-5).

Please refer to these publications for more information and for literature cited.

\section{Questions to be Addressed}

This field guide is meant to help personnel from management agencies, NGO's, environmental groups, and private landowners with a thought process of how to look at the landscape and determine what questions to ask to meet specified goals and objectives. These questions are meant to provide a base or starting point for selecting an appropriate preventive, maintenance, or restoration management action or post-wildfire management response. Because each management unit and its relationship to the surrounding landscape are unique, additional questions may need to be addressed or modified to help evaluate the site. The guide is separated into four parts important for identifying the attributes of an area and selecting the appropriate management action. These components help to clearly define or set goals and objectives through identifying (I) The Ecological Site, (II) The Current State of the Site, (III) Landscape Considerations, and (IV) Selecting the Appropriate Management Action. The right questions also need to address agency procedures and meet the overall goals of the project. 


\section{Setting Goals and Objectives}

The following questions are written from the perspective of implementing a preventive, maintenance, or restoration treatment, but are easily adaptable for application to post-wildfire management responses. What is to be done to a site should be based on clear and measurable objectives. This field guide also can help managers evaluate the site and incorporate decisions into the Resource Management Plan, Land Use Plan, or Forest Plan of their agency.

1. What are the desired ecological conditions or how should the site look in $5,10,20$, or 50 years?

2. What vegetation changes need to occur on the site, and possibly over the surrounding landscape, to meet functional goals or habitat needs?

Answers to the questions in Parts I, II, and III are intended to help managers and others determine feasible goals and objectives for a particular site. As a result, goals and objectives should be re-evaluated as these questions are answered.

\section{Part I: The Ecological Site}

3. In which Ecological Province is the site located?

4. What is the elevation and topography?

5. What kinds of soils are present on the site?

6. How will the soils and physical features affect erosion and vegetation establishment?

7. What are the dominant plant species currently present, and what is the current and future potential natural vegetation (PNV) or plant association?

8. Are there old-growth trees on the site, and where are they growing?

9. Is the PNV estimated to be woodland or shrubsteppe, and what is the estimated fire return interval?

10. What is the ecological site? 
11. Prior to European settlement, what would the potential disturbance regime (frequency, intensity, and kinds of disturbance) have been, and how would different scenarios of this regime influence the historic range of vegetation variability on the site?

12. How have post-settlement changes in vegetation or disturbance affected the vegetation and ecological conditions of the surrounding landscape?

13. What is the potential wildlife habitat value under current compared to potentially restored conditions?

\section{Part II: The Current State of the Site}

14. Clearly define the perceived problems: What are the factors affecting proper ecological function?

15. What is the stage of woodland succession (Phase I, II, or III), and how does this vary across the site?

16. What is the current understory herbaceous composition?

17. Is there current recruitment of native understory species?

18. Are there invasive plant species adjacent to the site to be treated?

19. What is the percentage of dead shrubs on the site, and what are the species?

20. What are the fuel characteristics, and what type of fire will the site support?

21. Are there signs of erosion and overland flow? What is the current capacity of the site to capture, store, and safely release water? What is the incidence of high-intensity summer thunderstorms?

22. What is the current wildlife habitat suitability, and what species are involved? How will treatment affect wildlife species?

23. Are there social and/or economic concerns or issues related to the site? 
24. What are the spatial landscape characteristics of the area to be treated with respect to topography, patch size, edge, and connectedness?

25. What is the composition of adjacent patches, what is the landscape distribution of patches, and what are their stages of woodland succession?

26. What is the current variation in understory composition and in the recruitment of native understory species over the surrounding landscape?

27. How do fuel characteristics of tree, shrub, and herbaceous layers vary over the surrounding landscape, what type of fire are they likely to support, and how might this influence the types of fire possible on the site?

28. Are there signs of erosion and overland flow from the surrounding landscape that suggest impacts to the site?

29. Will conditions of the surrounding area influence the wildlife habitat suitability of the site or affect the species involved?

30. What are current uses, management activities, and social and economic concerns for the surrounding landscape that might affect the site?

\section{Part IV: Selecting the Appropriate Management Actions and Treatments}

31. What are the factors that will influence selection of preventive, maintenance, or restoration treatments, including personnel availability, grazing schedules, and wildlife risk?

32. What are treatment options, including mechanical, prescribed fire, cut and burn combinations, chemical applications, and seeding?

33. How will post-treatment management, including the need for maintenance on the site, affect site conditions and function on the surrounding landscape? 


\section{Setting Goals and Objectives}

1. What are the desired ${ }^{1}$ ecological conditions or how should the site look in $5,10,20$, or 50 years?

Desired $^{1}$ ecological conditions depend on management objectives, potential uses for the site, and ecological characteristics of the site, such as soil profiles and ecological site type. Managers need to identify conditions that are ecologically, physically, and economically possible on a given landscape and that will satisfy management objectives over the longterm. Knowing these conditions can help determine if a treatment or series of treatments could help to achieve those results.

Setting goals and objectives will often require participation by stakeholders, who may have differing or even conflicting ideas about the values that should be emphasized in woodland-dominated ecosystems such as the appropriate ecological condition of those lands. Natural disturbances and changes in environmental conditions, such as those associated with climate change, also may affect the site and necessitate adjustments in management plans.

Because goals and objectives are influenced by many factors, they should be reevaluated and adjusted as new information becomes available. Answers to the questions that follow will provide information for managers and others that will help them in the ongoing

\footnotetext{
${ }^{1}$ Words such a "desired", or "desirable", and "best" are sometimes used to describe advantageous or suitable management approaches relative to management goals and objectives and in considerations of ecological responses of vegetation, soils, hydrologic function, and wildlife. These terms are used with recognition that many factors besides the evaluations described or cited in this manual may eventually come to bear in a decision-making process. In this context, these words should be viewed as relative terms only, not explicit directives or judgments.
} 
process of setting appropriate goals and objectives for a particular site.

2. What vegetation changes need to occur on the site, and possibly over the surrounding landscape, to meet functional goals or habitat needs?

After a "desired condition" has been defined (for example, fig. 6), the next step is to identify the specific vegetation changes necessary for the site to meet functional goals, such as improved watershed health or wildlife habitat. For example, an increase in shrubs and herbaceous vegetation may be needed to increase vertical structural diversity for wildlife. Also, a reduction in trees can reduce evapotranspiration, thereby increasing soil moisture and water availability. Maintaining an open tree canopy with a diverse understory may help achieve these habitat goals. An increase in shrubs could change structural diversity to affect fuels and maintain a desired fire regime. Increases in perennial grass and forb cover may reduce erosion and sedimentation and

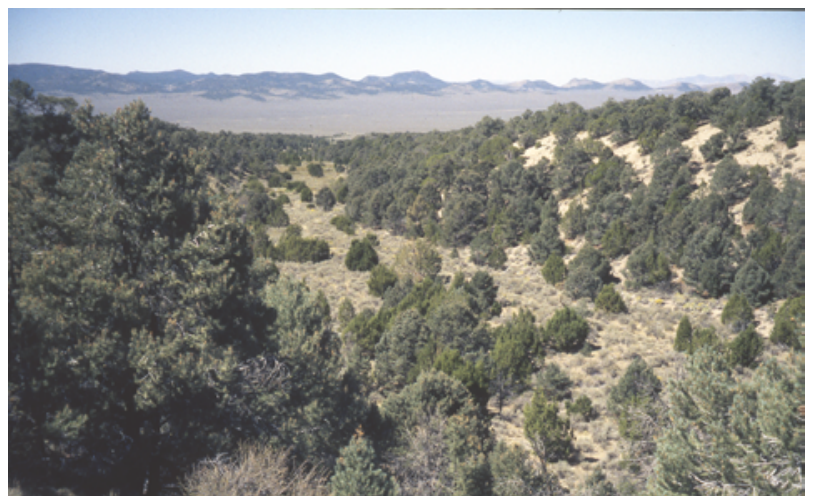

Figure 6. Phase II woodland. A management objective for this site might be to maintain a diverse understory by reducing tree dominance. 
also enhance the ability of the site to capture and store water. In addition, increases in perennial grass and forb cover often can decrease the invasion of potential exotic species. All of these vegetation changes could help in meeting the desired goal of watershed health or wildlife habitat.

\section{Part l: The Ecological Site}

Determination of the Ecological Site is based on the premise that specific physical and climatic characteristics are capable of producing certain types of vegetation. Ecological site and soil maps for the area should be obtained and used to help determine the proper ecological site description, soils, and potential vegetation. Maps should be verified during a site visit to ensure that the descriptions match the site.

\section{In which Ecological Provinces is the site located?}

The Great Basin is a region of complex topography, geology, and climate. The mountain ranges and intervening valleys vary greatly in size, elevation, configuration, and climate, all of which significantly affect vegetation. Environmental conditions on a particular mountain range are dependent not only on the topographic characteristics of the mountain range the site is located on, but also on the topographic characteristics and configuration of the surrounding ranges and valleys. Woodlands within Ecological Provinces are more similar in climate, topography, elevation, geology, soils floristic composition, and soil-plant relations than those across Ecological Provinces. Most of the dominant tree, shrub, and perennial grass species have wide ecological 
tolerances, and thus are expected to have more uniform responses within an Ecological Province compared to anywhere else they occur. A species response to disturbance or treatment may vary depending on the species location. Differences between the Ecological Provinces in altitude, topography, environment, geology, and vegetation can affect the outcomes of natural disturbances or treatments. The different Ecological Provinces are illustrated in figure 7.

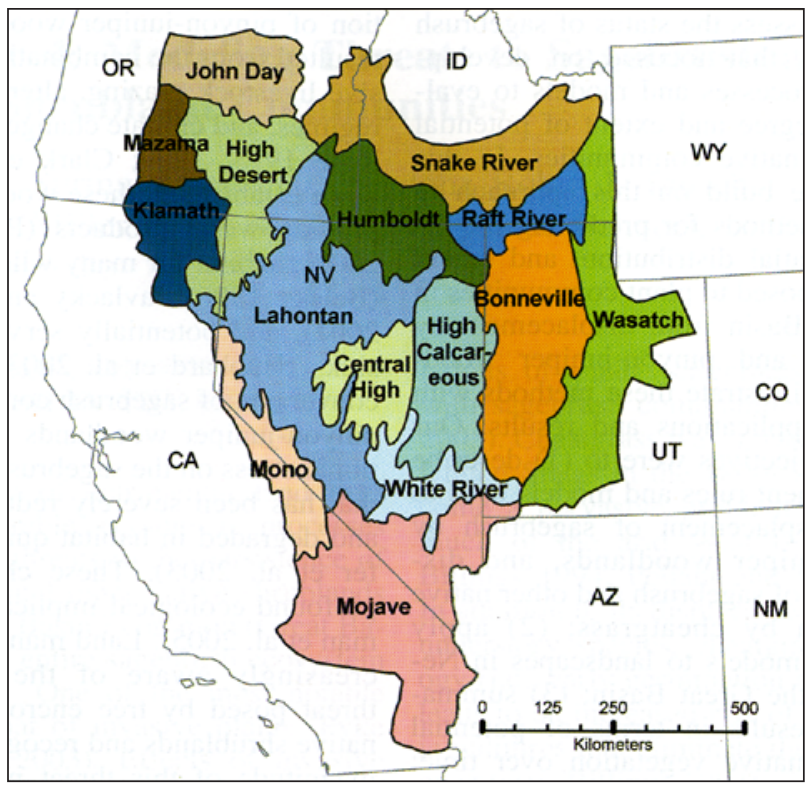

Figure 7. Ecological Provinces of the southwestern United States. Adapted from West, N.E., R.J. Tausch, and P.T. Tueller. 1998, A management-oriented classification of piñon-juniper woodlands of the Great Basin: U.S. Forest Service General Technical Report RMRS-GTR-12. 


\section{What is the elevation and topography?}

Within the complex geology of the Great Basin, topography (primarily slope and aspect) combined with elevation can have a substantial effect on the soil type and the plant community. These factors influence how a site will respond to natural disturbance and applied treatments. For example, resilience and resistance to disturbance and potential for successful restoration often increases with elevation and more northerly aspects. Increasing elevation and shifts in aspect from south to north often result in cooler temperatures, greater moisture availability, and more productive soils. These differences also vary with Ecological Province, site topography, the spatial relatiohship, and topographic differences of surrounding mountain ranges.

\section{What kinds of soils are present on the site?}

A soils map of the site or area will indicate what type of soils are present. Soil depth, texture, structure, and organic matter content are important soil characteristics that influence water infiltration rates, water holding capacity, soil water availability for plants, and erosion potential. Loamy soils, which have a more balanced mixture of sand, silt, and clay (fig. 8) have better soil-water characteristics for plant growth than excessively drained sandy soils with low water-holding capacity or clay soils with low infiltration rates and very tightly held water.

Soil Texture (fig. 8): To determine soil texture of each horizon, add water to a healthy tablespoon of soil until you can roll it up in a ball without it leaving soil on your palm. 
Press the soil between your thumb and forefinger and attempt to form a ribbon.

- Good Ribbon: does not break and has few cracks = high clay content

- Medium Ribbon: ribbon cracks deeply and eventually breaks $=$ moderate clay content

- Poor Ribbon: a ribbon cannot be formed or immediately breaks $=$ low clay content Add additional water and test for smoothness and grit. Gritty texture indicates sand.

Soil Depth: Soil depth is measured from the surface to the layer that retards root development:

Very shallow: $<10 \mathrm{in}$.

Shallow: 10 to $20 \mathrm{in}$.

Moderately deep: 20 to 36 in.

Very deep: $>60$ in.

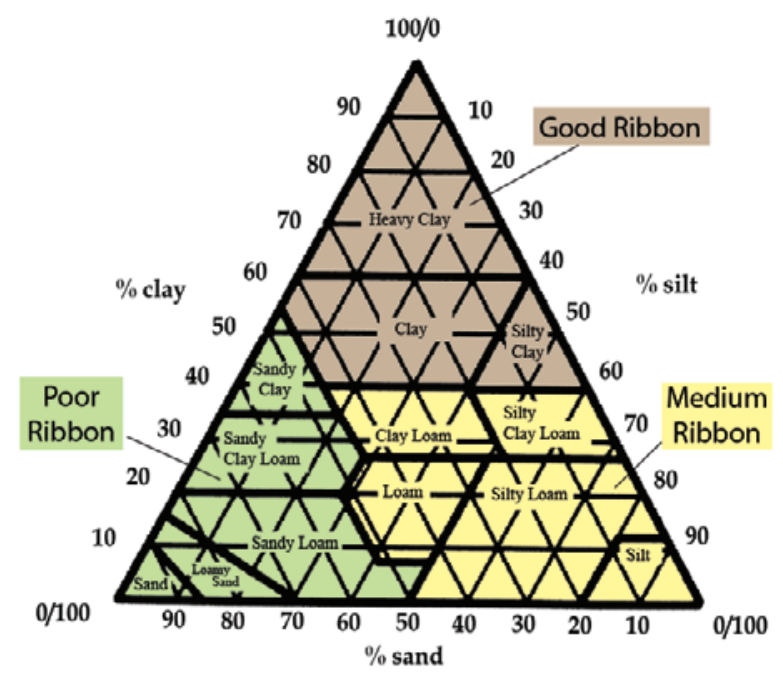

Figure 8. Soil texture triangle (from Miller and others, 2007). 
Restrictive soil layers increase below-ground competition. With increasing tree dominance, herbaceous vegetation is likely to decrease on sites where there is a restrictive soil layer 16 to 18 in. beneath the surface. Soil layers (for example, heavy clay argillic layer, petrocalic horizon, duripan, lithic contact, etc.) that restrict water movement also will influence water runoff on the site (fig. 9), and this should be considered before treatment. Where increasing tree dominance is causing the greatest decrease in understory (fig. 10) are often sites that are most susceptible to exotic annuals such as cheatgrass.

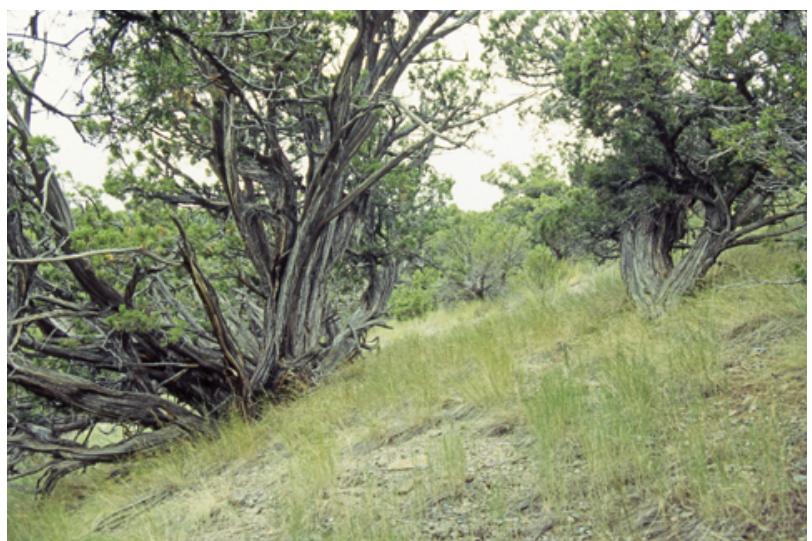

Figure 9. Mountain big sagebrush/ldaho fescue plant association with moderately deep (>30 in.), well-drained, clay loam soils. Juniper roots are well distributed throughout the soil profile resulting in a loss of shrubs, but Idaho fescue persists in the understory. 


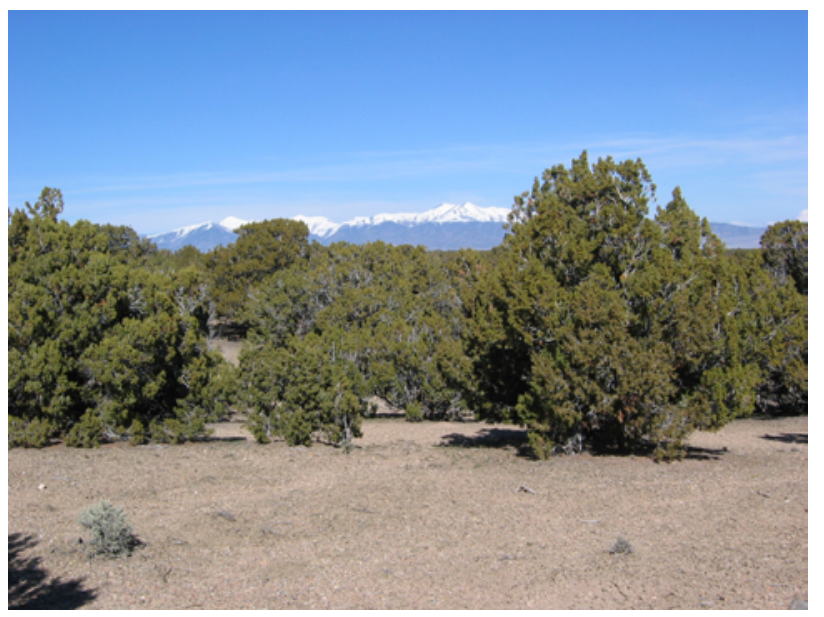

Figure 10a. A shallow restrictive soil layer limits tree rooting depth resulting in a loss of shrubs, grasses, and forbs.

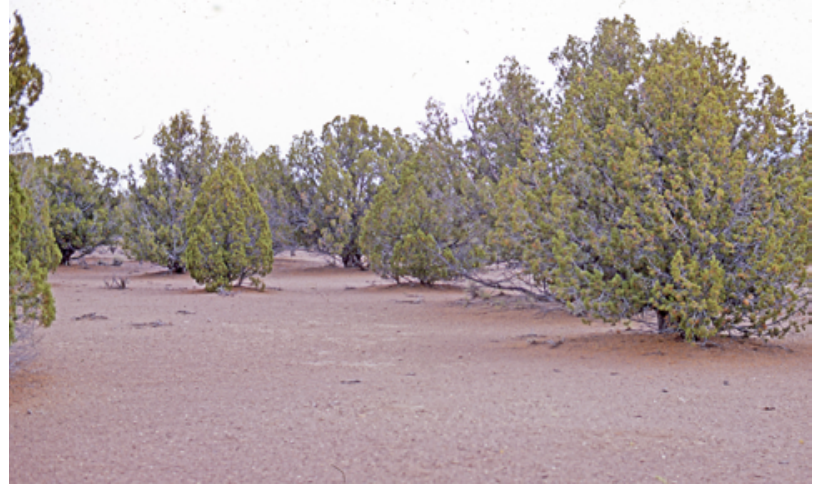

Figure 10b. Former Wyoming big sagebrush community on a site with a restrictive soil layer similar to fig. 10a now fully dominated by Utah juniper. 
6. How will the soils and physical features affect erosion and vegetation establishment?

Soil surface characteristics, slope, incidence of intense summer thunderstorms, and wind influence risk of erosion following tree removal treatments. Soil surface stability, soil texture, soil depth, aggregate stability, patterns of bare ground, and evidence of rill and sheet erosion should be examined across the site. These factors in combination with slope interact to determine erosion potential. Treatments like prescribed fire may remove vegetation cover, and the site may be vulnerable to erosion in the short term. Soil can be protected by methods such as cutting or masticating the trees and leaving the slash or chips on the ground. Another factor to consider is whether past erosion due to tree dominance has changed soil characteristics in ways that will affect the success of seeding. For example, has enough topsoil been lost to significantly reduce the seedbed for seed germination or the rooting zone of seeded species?

7. What are the dominant plant species currently present, and what is the current and future potential natural vegetation (PNV) or plant association?

- Which tree species, sagebrush species or subspecies, other shrubs, and perennial grass species are present on the site (key 1 and figs. 11-13; if Phase III, look for shrub skeletons on the site)?

- Is there evidence that pre-settlement trees occupied this site in the past (table 1, key 2)?

- What are some of the diagnostic perennial grass and forb species (fig. 12)? 


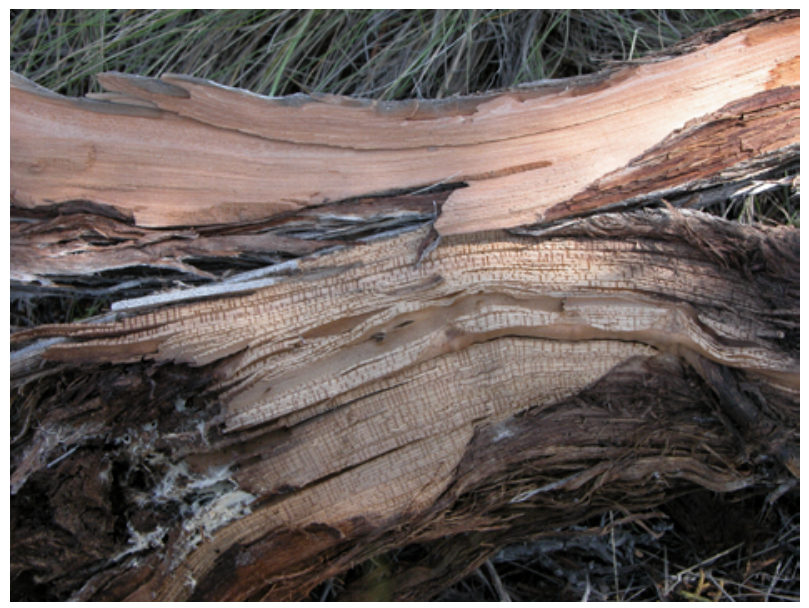

Figure 11. Dead bitterbrush and big sagebrush remnants can be distinguished by differences in the wood; bitterbrush (top) is clear while sagebrush (bottom) has dark brown bands perpendicular to the annual growth rings (from Miller and others, 2005).

Warm-Dry Cool-Wet (generally low elevation)

(generally high elevation)

Sagebrush

ARARLO $<$ ARAR $<$ ARNO $<$ ARTRWY

$<$ ARTRTR $<$ ARTRVA

Other Shrubs

TECA $<$ GRSP $<$ PUTR $<$ AMAL $<$ SYMSPP

Perennial Grasses

ACSP12 < ACHY < HECO26 < PSSP

$<$ ACTH7 $<$ FIED $<$ BRCA

Figure 12. Diagnostic sagebrush community species oriented along a general warm-dry to cool-wet gradient (for definitions of plant codes see appendix 2). Low sagebrush (ARAR) also occurs at high elevations on shallow soils and topographic locations that limit available soil moisture. 
Key 1. Common sagebrush species and subspecies associated with piñon-juniper woodlands (figs. 13a-k). Key is based on persistent leaves and flower stalks. This key is for preliminary identification only. Final identification should be based on additional taxonomic information.

1a. Mature shrubs $<20$ in. tall.

2a. Flowers early summer, leaves broadly cuneate, with deep, well developed lobes, center lobe often buck-toothed (wider than space between two outer leaves) (fig. 13a) ............... early sagebrush

2b. Center lobe usually not buck-toothed, flowers mid-summer to fall

3a. lowering stalks gray pubescent, weakly persistent, leaves grayish green, not sticky or glandular (figs. 13b-c) ........ low sagebrush

3b. Flowering stalks brown to straw colored, persisting into the following year, leaves usually darker green and sticky glandular (figs. 13d-e) black sagebrush

1b. Mature shrubs $>20$ in. tall.

4a. Plant even topped or flat-crowned, flower stalks mostly $>1 / 2$ above vegetative shoots, leaves wedge shaped and tapered to base with straight margins, leaves fluoresce bluish white under ultraviolet light (figs. 13f-g) ............. mountain big sagebrush

4b. Plant crowns uneven, flower stalks throughout the crown, usually $<1 / 2$ above crown, does not fluoresce bluish under ultraviolet light.

5a. Plants usually $>3 \mathrm{ft}$ tall, mature persistent leaves 4 times as long as wide or longer with straight margins (figs. 13h-i) ............ basin big sagebrush

5b. Plants usually $<3 \mathrm{ft}$ tall, mature persistent leaves less than 4 times long as wide, margin curves outward giving bell shaped leaves (figs. 13j-k) .......... Wyoming big sagebrush 
Figure 13. Common sagebrush species and subspecies associated with piñon-juniper woodlands.

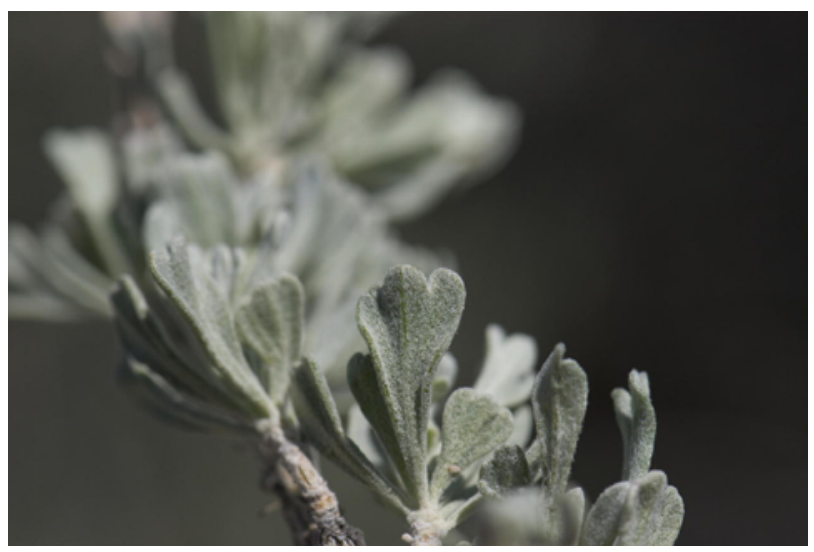

(a) Leaves of early sagebrush 
Figure 13. Continued.

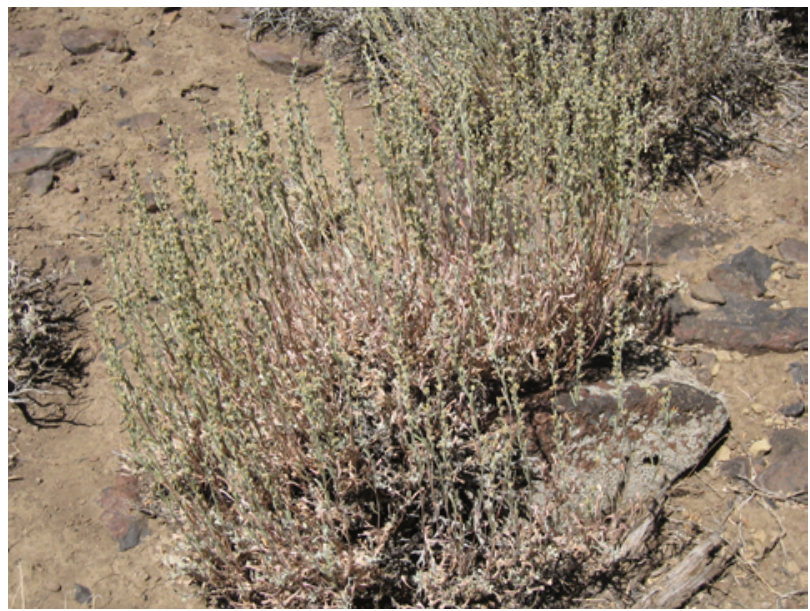

(b) Crown of low sagebrush

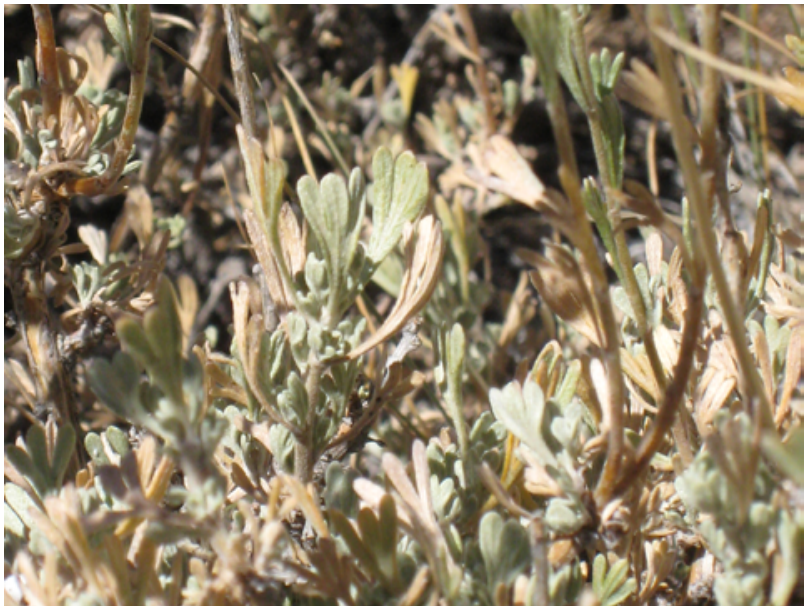

(c) Leaves of low sagebrush 
Figure 13. Continued.

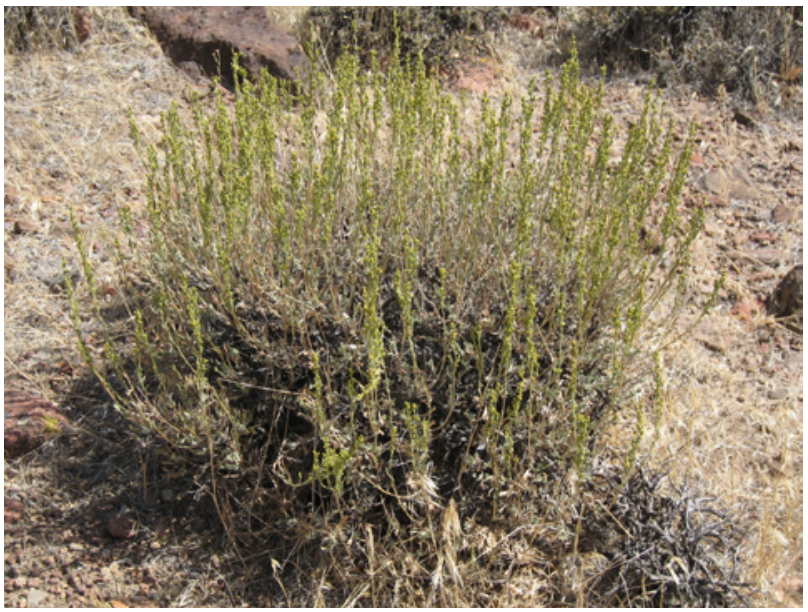

(d) Crown of black sagebrush

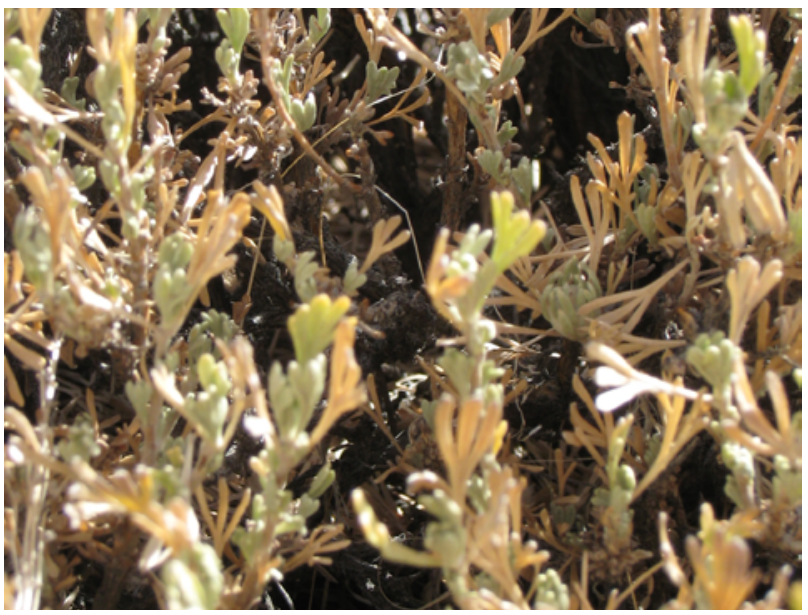

(e) Leaves of black sagebrush 
Figure 13. Continued.

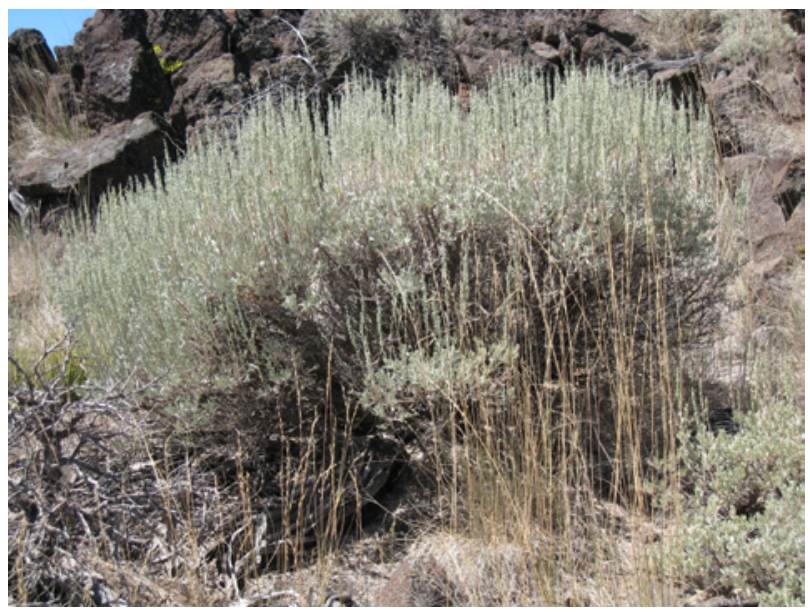

(f) Crown of mountain big sagebrush

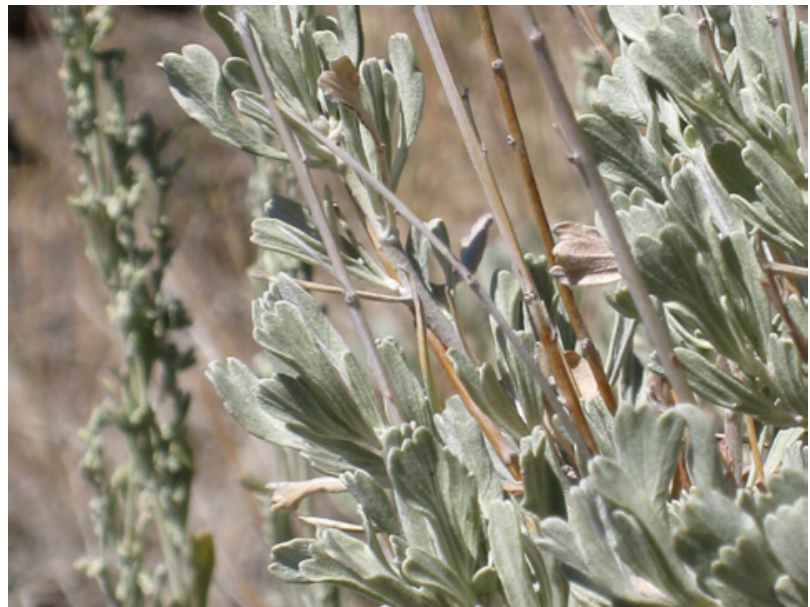

(g) Leaves of mountain big sagebrush 
Figure 13. Continued.

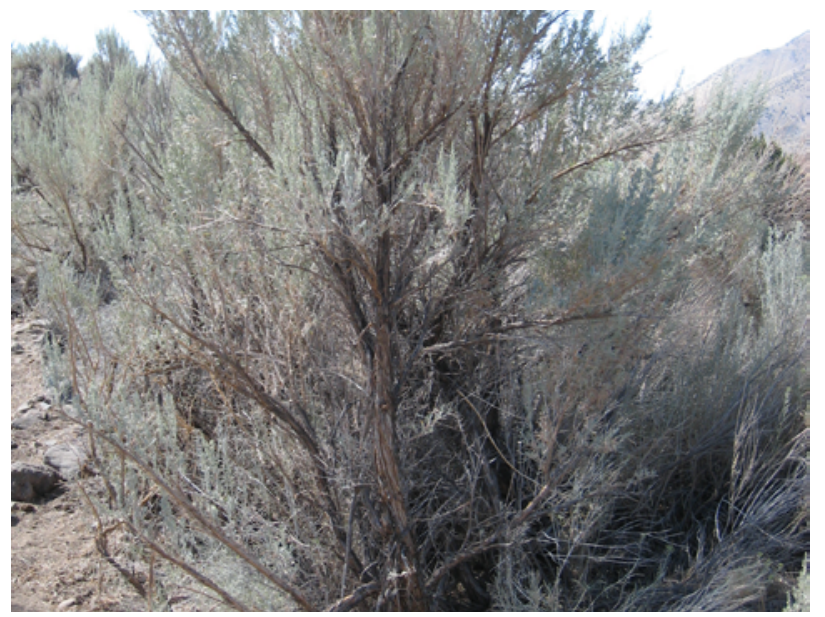

(h) Crown of basin big sagebrush

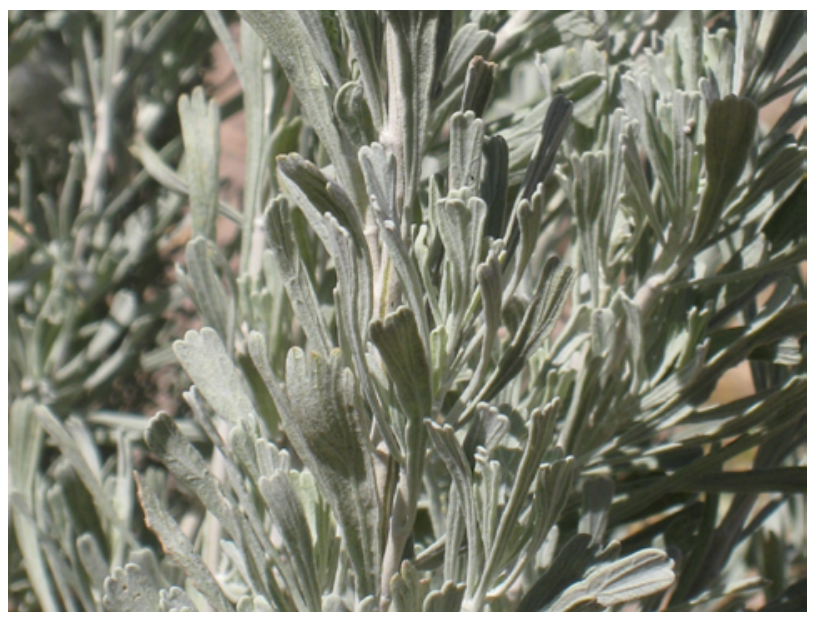

(i) Leaves of basin big sagebrush 


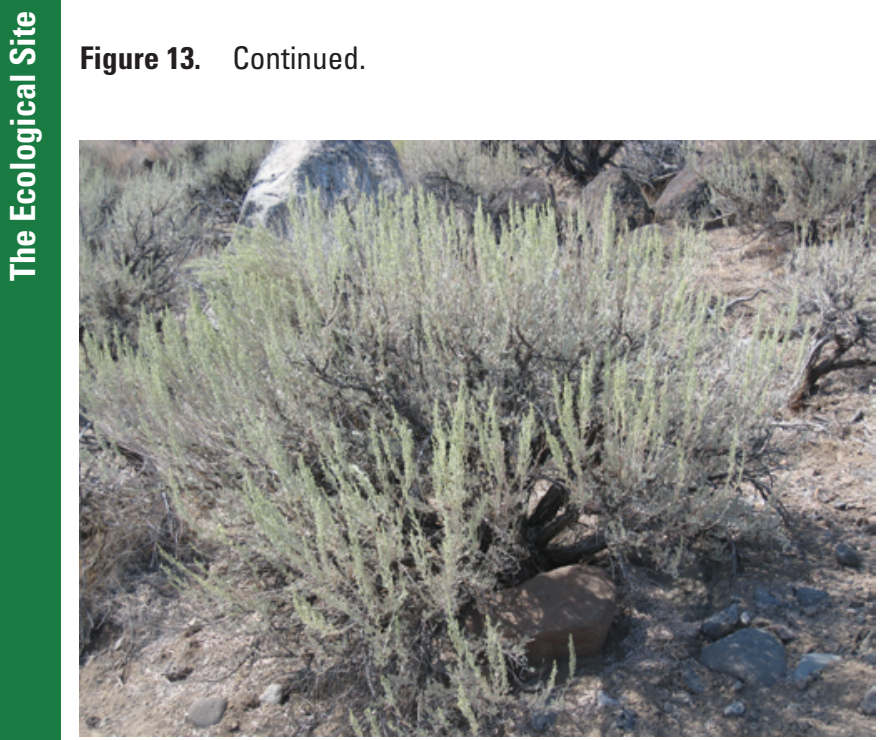

(j) Crown of Wyoming big sagebrush 
Figure 13. Continued.

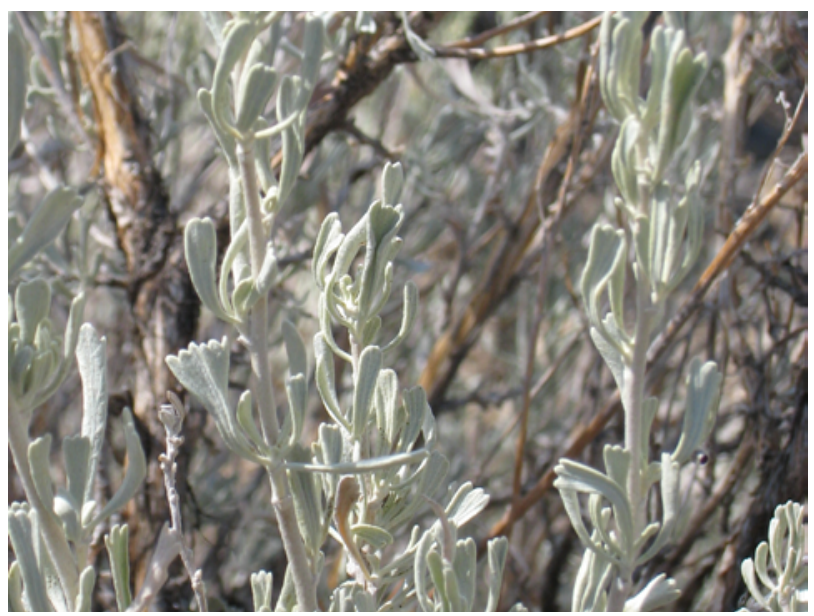

(k) Leaves of Wyoming big sagebrush 


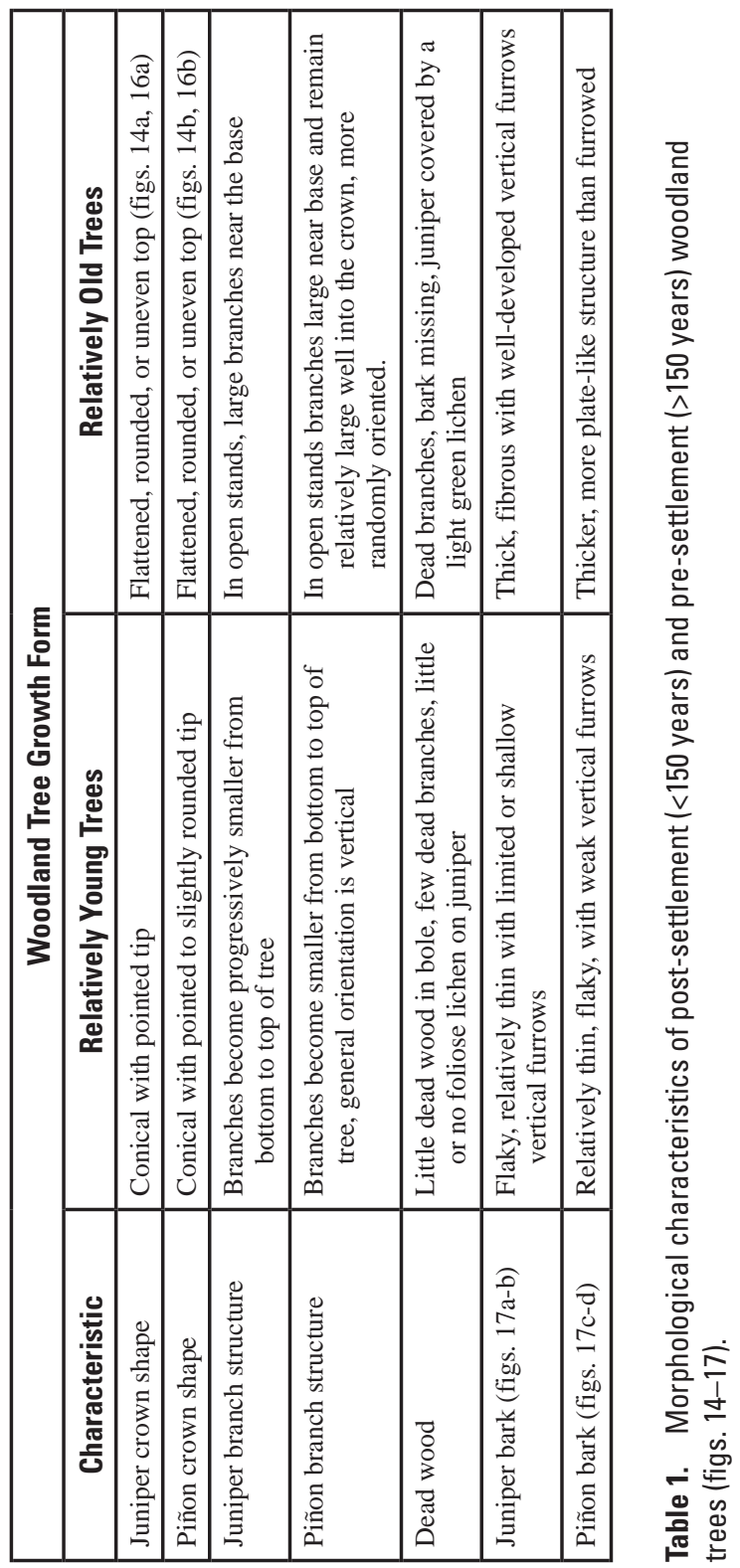




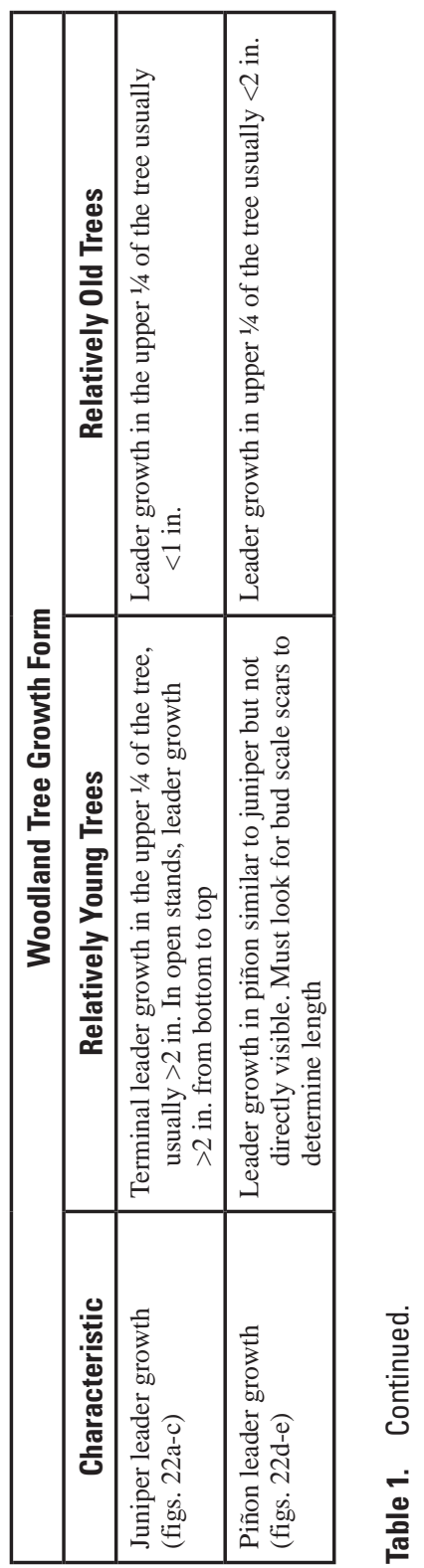

궁 


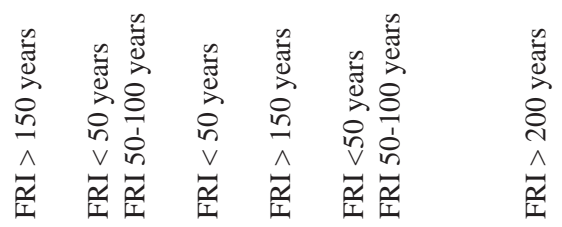

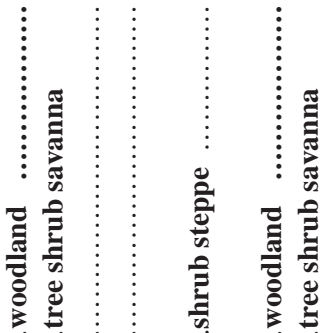

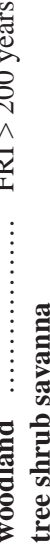

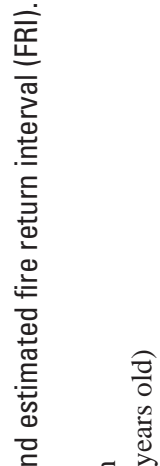

흥

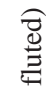

氙

:

ఏ.

$\vdots \frac{\infty}{0}$

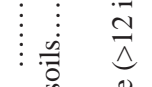

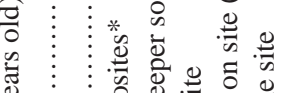

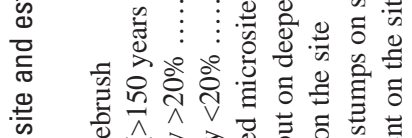

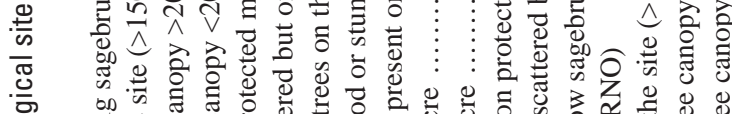

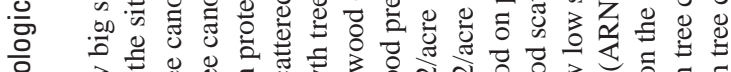

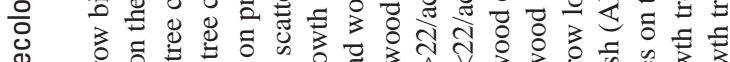

¿

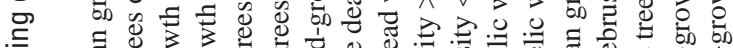

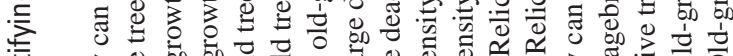

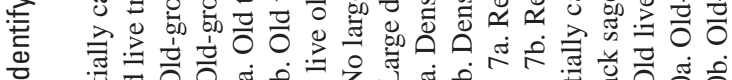

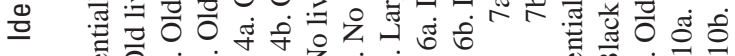

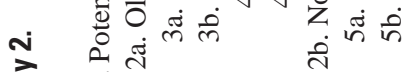

ฮิ

वृं

ஸे कं

อ 


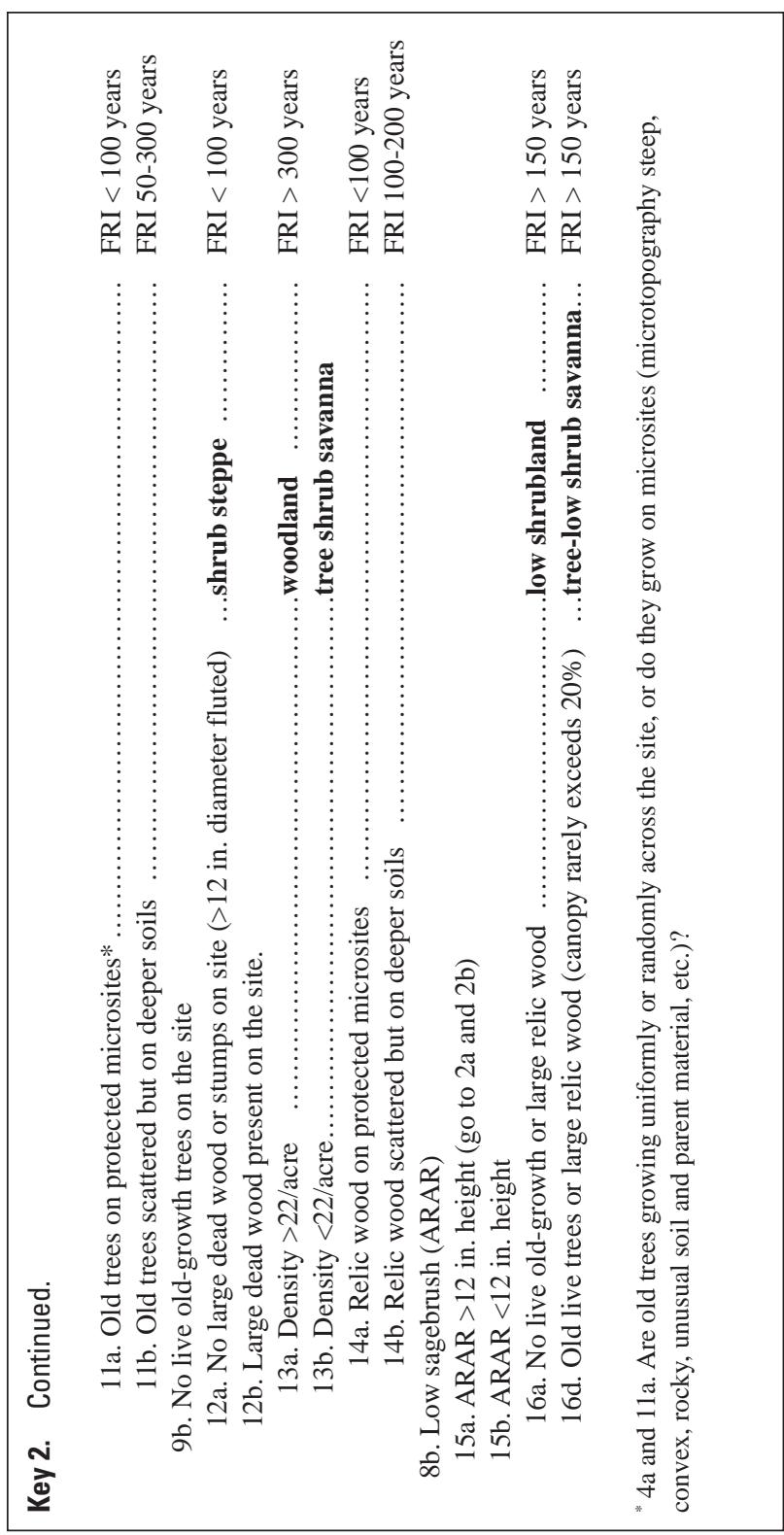


8. Are there old-growth trees on the site, and where are they growing (figs. 14-17)?

Old-growth trees have a long history on many locations in the region and have provided valuable wildlife habitat, added structural and biological diversity, and can be part of the PNV on many of these landscapes. For these reasons, it is important to identify areas where old-growth occurs and to carefully consider the appropriateness and consequences of any tree removal projects that might jeopardize or enhance the integrity of these sites. An appropriate action is the thinning of younger trees, particularly in adjacent areas, where there is a potential for them carrying a stand-replacement fire into the old-growth (fig. 14a). Old-growth trees are associated with various soils, landforms, and plant associations, but typically grow in rock outcrops or on steep slopes (fig. 14b) and have soils that are often shallow and course in texture. Old-growth juniper can occasionally have an understory of deep-rooted perennial grasses (fig. 14c), a situation not observed for piñon. Old-growth stands commonly grow in areas where accumulation of herbaceous fuels is limited, where stand-replacement or mixed-severity fires are infrequent, and where tree removal results in limited increases in understory productivity (fig. 15). 
Figure 14. Examples of the range of variation in old-growth woodland sites.

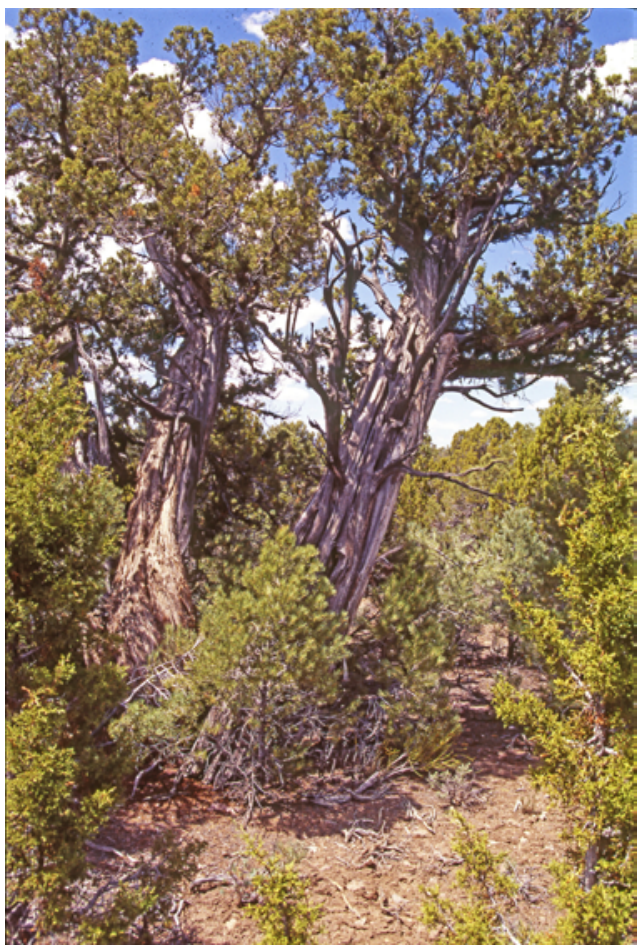

(a) Utah juniper in a former shrub savanna site that has experienced a recent large increase in tree density and fuel loads 
Figure 14. Continued.

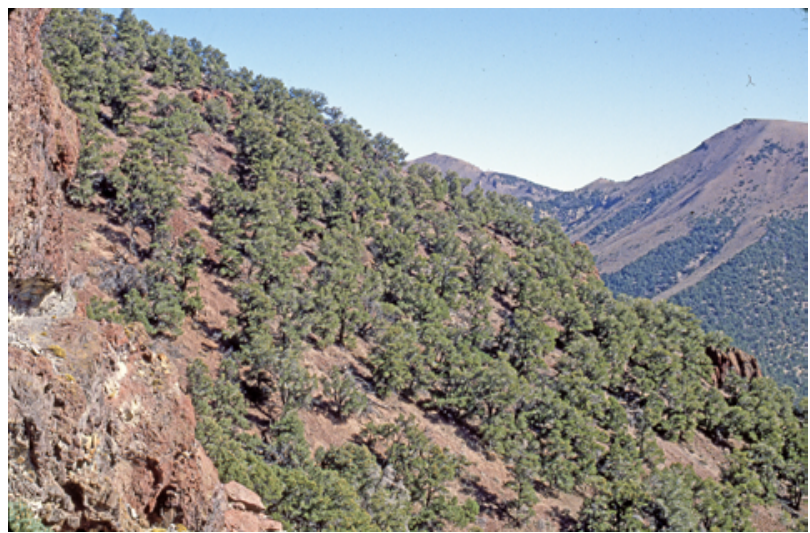

(b) An old-growth site dominated by piñon on a steep, rocky south-facing slope

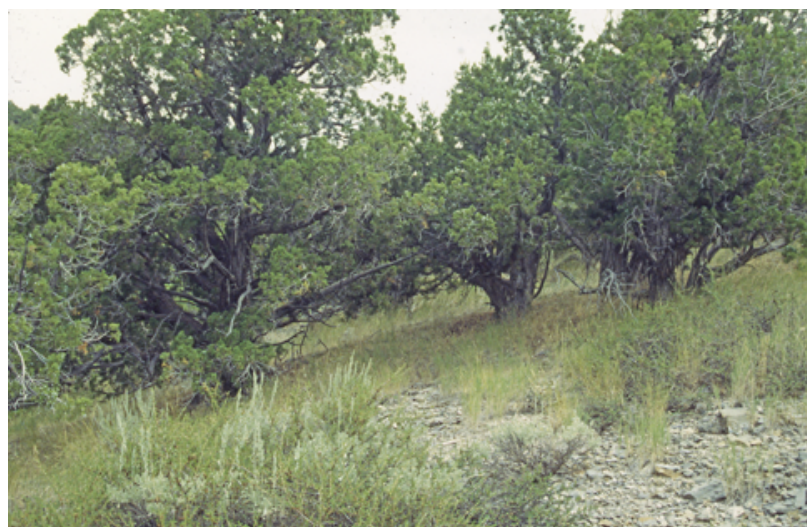

(c) An old-growth Utah juniper site in west central Utah 


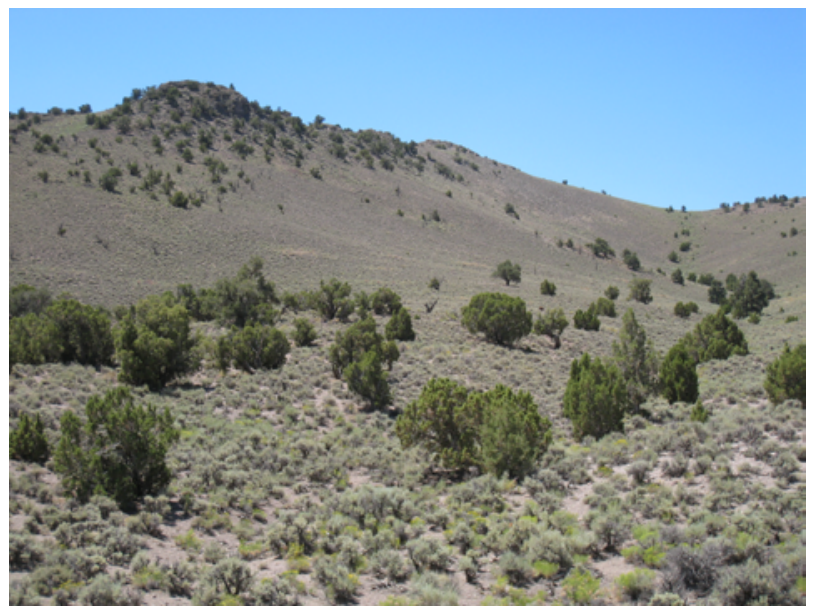

Figure 15. An open old-growth Utah juniper dominated shrub savanna in east-central Nevada.

Questions to ask to determine if the site is or was an oldgrowth site:

- Are there trees on the site showing old-growth characteristics (fig. 16), or are the trees $<150$ years old (table 1)?

- Do the soils typically support persistent woodlands, or do they have characteristics such as greater depth and mollic horizons that developed under a grass or grass-shrub dominated vegetation?

- Does tree structure suggest the site is relatively stable (limited recruitment), or are younger trees in-filling?

- Are there large stumps or snags (>18 in. but often > 24 in. in diameter), often covered with char?

- Are there large logs or branches lying on the site? 


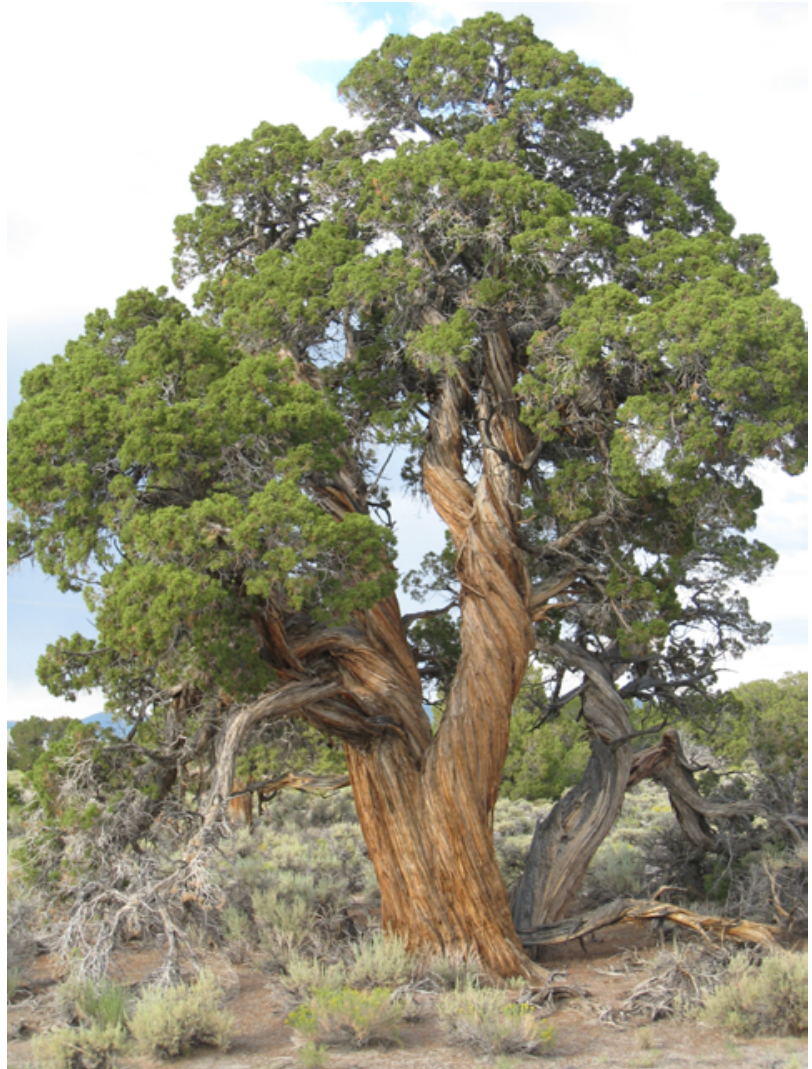

(a)

Figure 16. (a) Old-growth Utah juniper and (b) singleleaf piñon with dead branches and missing bark. 


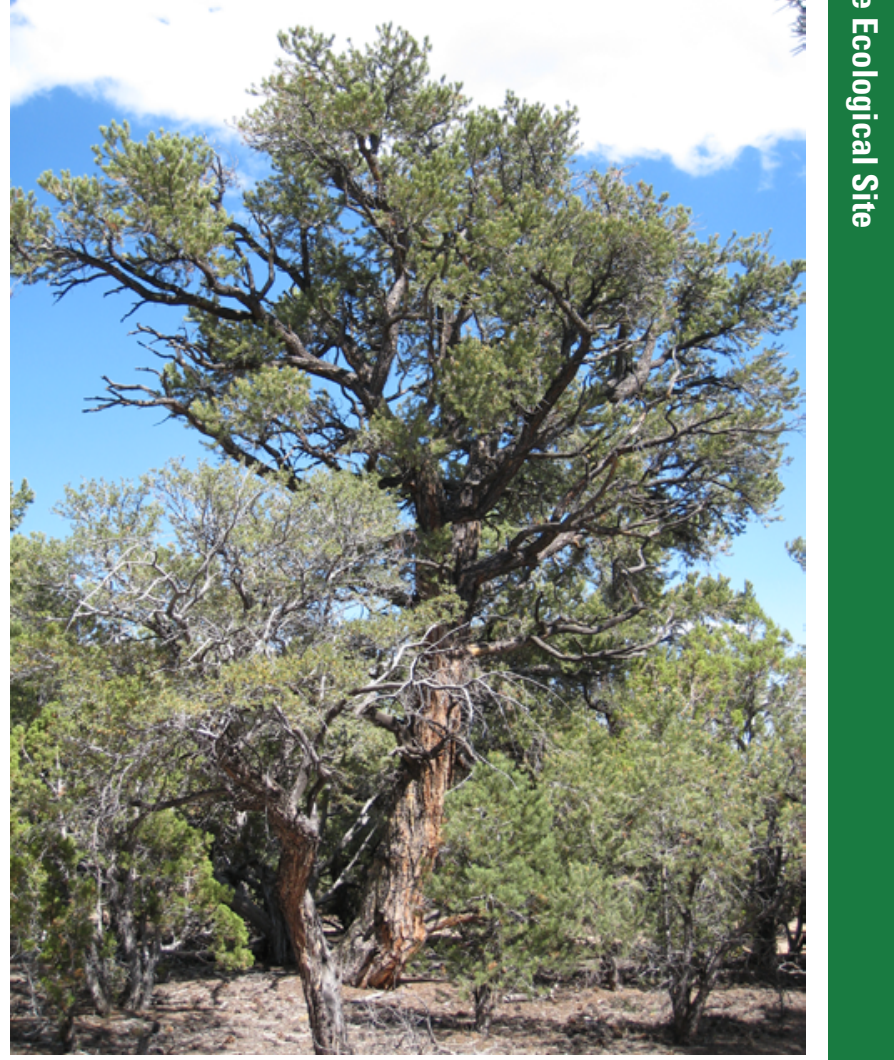

(b)

Figure 16. Continued. 


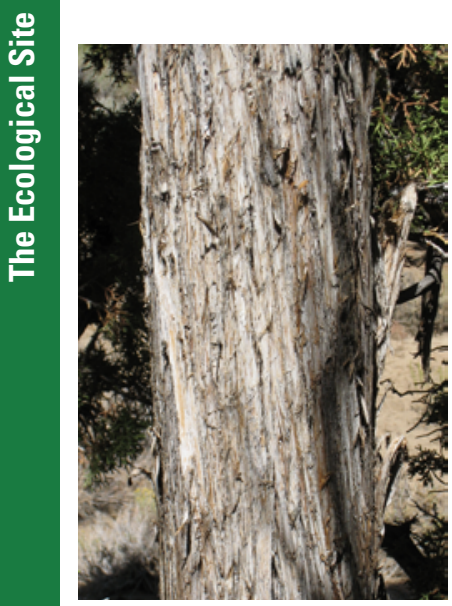

(a)

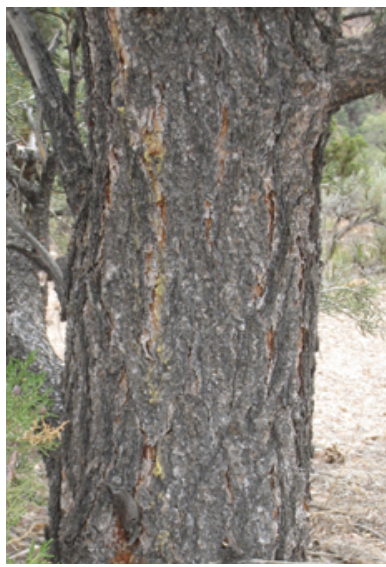

(c)

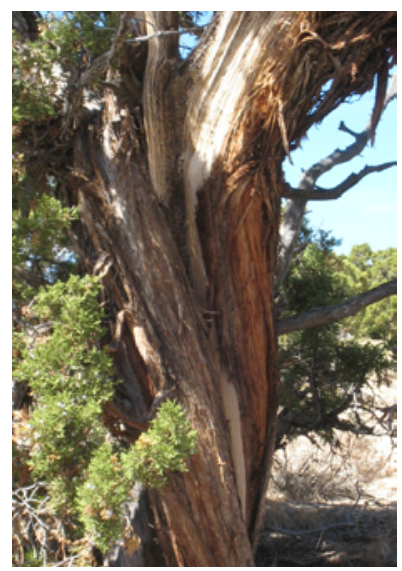

(b)

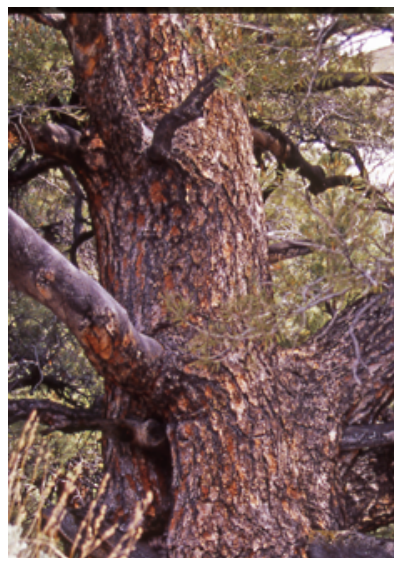

(d)

Figure 17. Bark characteristics of species of woodland trees of different ages. (a) At about 100-150 years, juniper bark is thin and flaky. (b) At over 300 years, juniper bark is thick and fibrous, with well-developed vertical furrows. (c) At about 100 years, piñon bark is thin, flaky, with weak vertical furrows. (d) At over 300 years, piñon bark is thicker, with a more plate-like structure than furrowed. 
9. Is the PNV estimated to be woodland or shrubsteppe, and what is the estimated fire return interval?

Key 2 can help identify the potential of the site as tree-shrub savanna (fig. 15), old-growth woodland (existing, fig. 18, or following disturbance, fig. 19), or shrub steppe. The key also gives an estimated fire return interval (FRI) for the site. Return intervals in the key are meant only as a coarse proxy of the number of years between fires prior to Eurasian settlement if other documentation is not available.

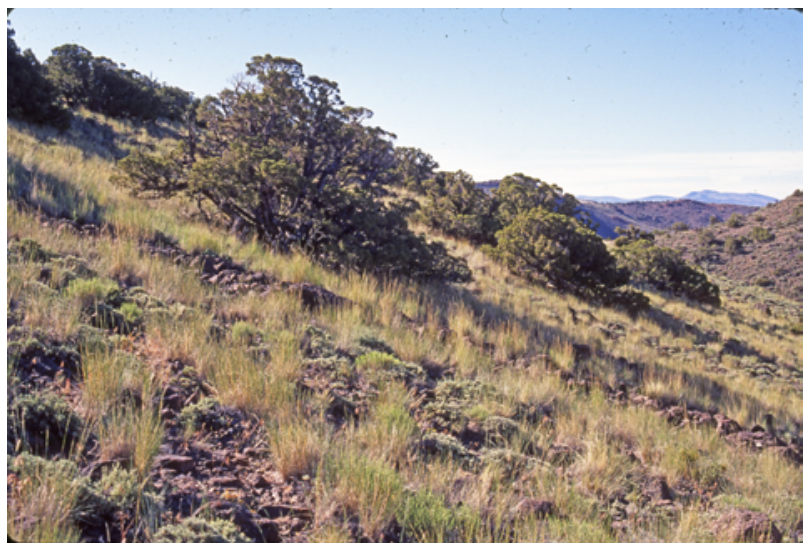

Figure 18. Mountain big sagebrush/bluebunch wheatgrass plant association with a stand of pre-settlement Utah juniper trees growing on shallow soils. 


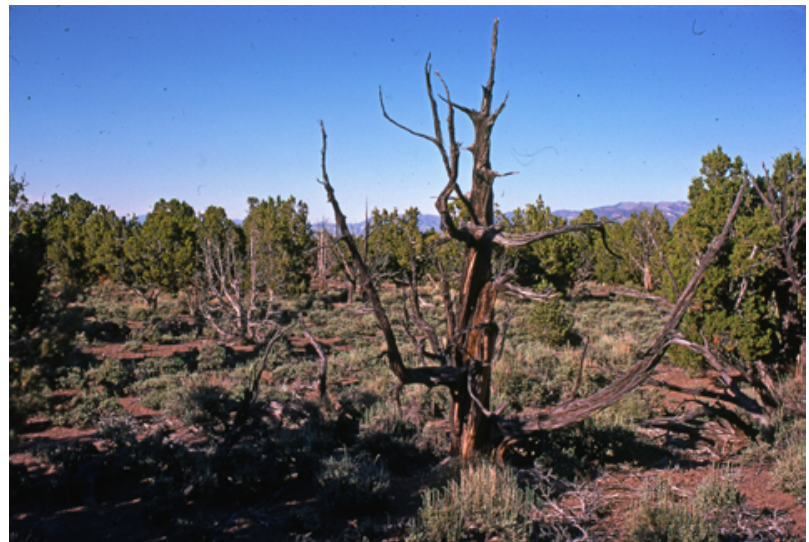

Figure 19. Wyoming big sagebrush community with charred stumps on shallow to moderately deep soils that indicate a low density of trees has occupied the site since prior to the mid1800 s.

\section{What is the ecological site?}

Identification of the ecological site identifies a site's ability to produce a distinctive kind and amount of vegetation and the interrelationships of that vegetation with other ecological sites over the landscape. The characteristics of an ecological site are based on its associated physiographic, climatic, soil, and water features; and on the plant communities comprising its various vegetation states. Information on the specific ecological site descriptions that are available can be accessed at http://esis.sc.egov.usde.gov/ESIS/.

\section{Prior to European settlement, what would} the potential disturbance regime (frequency, intensity, and kinds of disturbance) have been, and how would different scenarios of this regime influence the historic range of vegetation variability on the site? 
The kind and number of years between disturbance events, such as fire (refer to key 2), will help determine what kind of plant community is most persistent on a site (fig. 20). This can provide a baseline to use in gaging how much change has occurred. While conditions prior to settlement may not be replaceable, or be a viable management goal, the future possibilities for a site are not independent of the pre-settlement conditions.

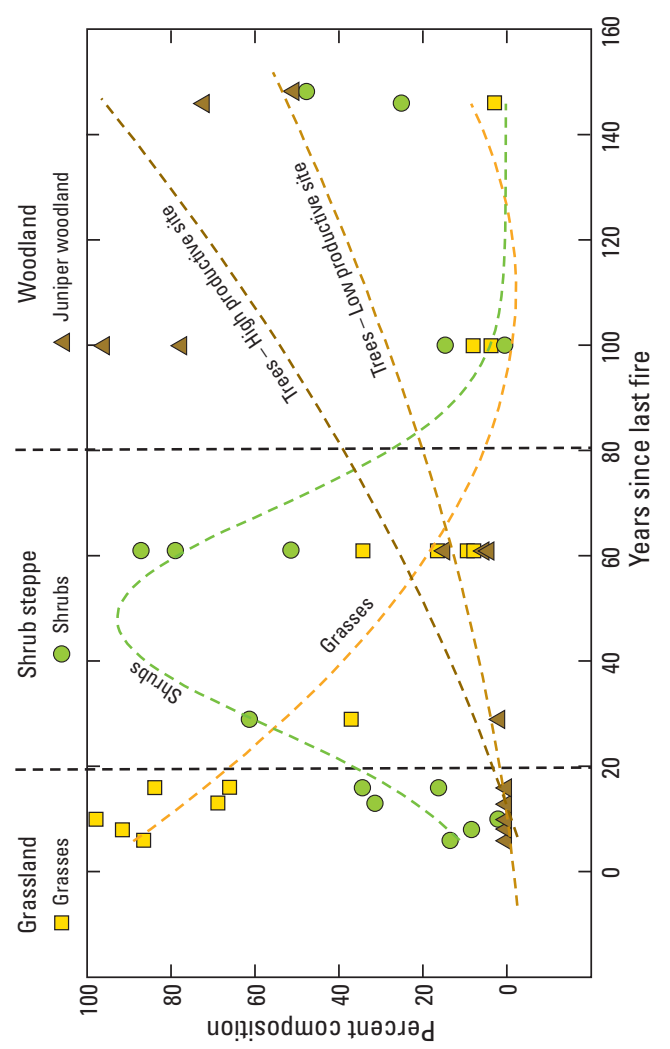

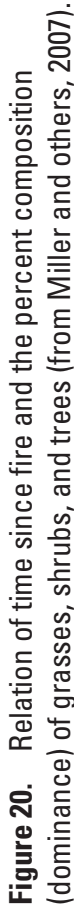


12. How have post-settlement changes in vegetation or disturbance affected the vegetation and ecological conditions of the surrounding landscape?

For example, in some areas scattered old trees that have survived historic fire regimes are currently at risk as a result of post-settlement infill of younger trees or woodland expansion into sagebrush areas adjacent to old-growth patches (fig. 14)

13. What is the potential wildlife habitat value under current compared to potentially restored conditions?

Would vegetation on the site and surrounding area support sensitive wildlife species (that is sagebrush obligates, such as sage grouse, or species seasonally dependent, such as mule deer) (fig. 21)?

- Is it important seasonal habitat (that is, key winter, nesting, brood rearing habitat that is being lost to tree expansion)?

- Would treatment result in improved connectivity between other habitats?

- What vegetation layers (herb, shrub, tree) should be present and in what relative proportion? 


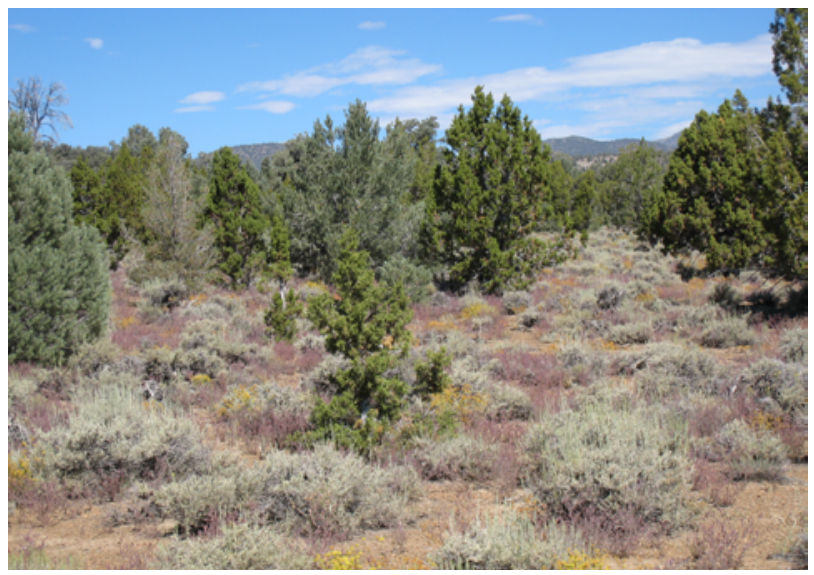

Figure 21. Phase II piñon-juniper expansion woodlands in a mountain big sagebrush community with a high level of structural diversity.

\section{Part II: The Current State of the Site}

14. Clearly define the perceived problems: What are the factors affecting proper ecological function?

An important attribute that affects proper ecological function is vegetation structure, specifically the amount, type, and distribution of plant ground cover. If the site is not functional with respect to water and nutrient cycles or soil or biotic integrity, physical conditions that are connected to the problem need to be identified. Site condition should be evaluated to determine if an imbalance in plant community composition, a lack of structural diversity in the vegetation community, or a high proportion of bare ground are contributing factors. With the encroachment or increasing density of trees, the best way to maintain or restore hydrologic function and soil or biotic integrity is to implement treatments that reduce tree dominance while ensuring recovery 
or maintenance of understory vegetation, particularly perennial herbaceous species, on the site. Additional factors that might be weighed in treatment decisions include multiple management objectives (for example, wildlife habitat and fuels management), economic costs/ benefits, and social values.

\section{What is the stage of woodland succession} (Phase I, II, or III), and how does this vary across the site?

The stage of woodland development can influence the type of treatment selected, follow-up treatments and management, understory competition, seed pools, and vegetation response following management action. Patterns of woodland development and understory loss are much the same regardless of which species dominate. There are three transitional phases of woodland development (figs. 22-25 and table 2):

- Phase I - trees are present but shrubs and grasses are the dominant vegetation that influence ecological processes (hydrologic, nutrient, and energy cycles) on the site;

- Phase II - trees are co-dominant with shrubs and herbs, and all three vegetation layers influence ecological processes on the site;

- Phase III - trees are the dominant vegetation and the primary plant layer influencing ecological processes on the site. Shrubs no longer dominate the understory.

Stand characteristics can be used to classify woodland development according to these phases. Early indicators of site dominance include shrub canopy mortality and reduction of leader growth on tree saplings (<10 ft tall). Leader growth patterns are similar for western and Utah juniper, but only directly visible for piñon when the growth for the year is still in the 'candle' 
stage (fig. 22). That is, the stem growth for the year has been completed, but needle elongation has not. Once needle elongation in piñon has been completed, it is necessary to locate the bud-scale scars from the previous fall's terminal bud to determine leader growth. The number of years between initial tree encroachment and stand closure is largely determined by the rate of establishment and climate conditions. On most piñonjuniper sites, stands shift from Phase II to III within 100 years after the first trees establish.

Figure 22. Leader growth, particularly for trees $<3 \mathrm{~m}$ tall, is a good indicator of competition among trees. Although similar patterns exist for juniper and piñon, leader growth is only directly visible in the latter when in the 'candle' state.

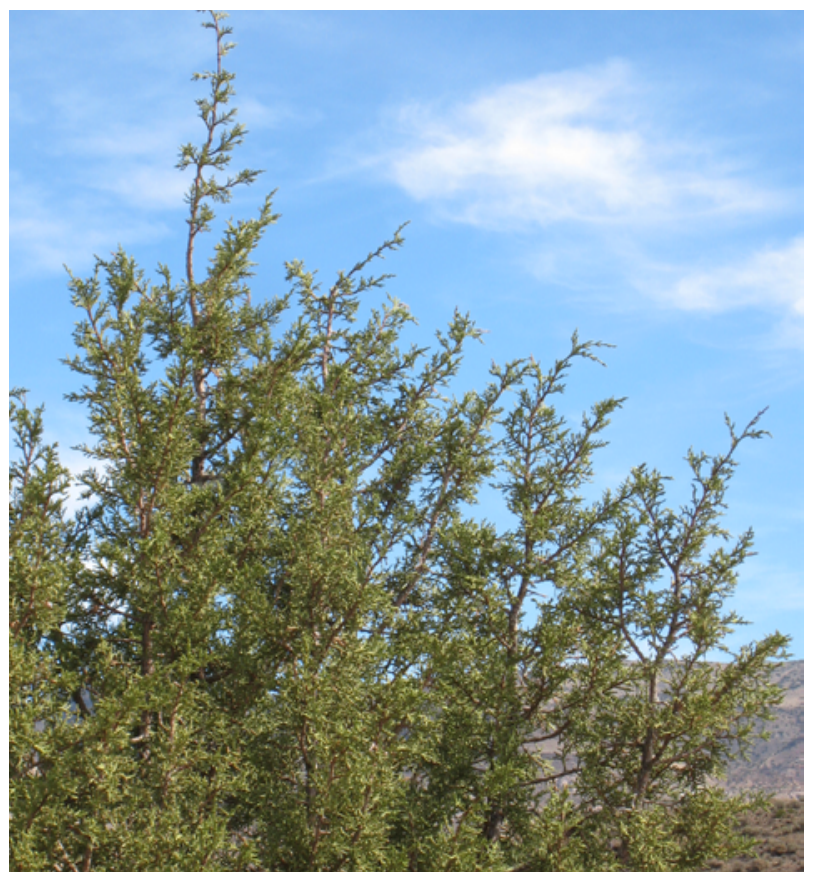

(a) Utah juniper leader growth in Phase I woodlands 


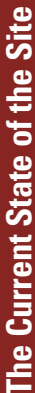

Figure 22. Continued.

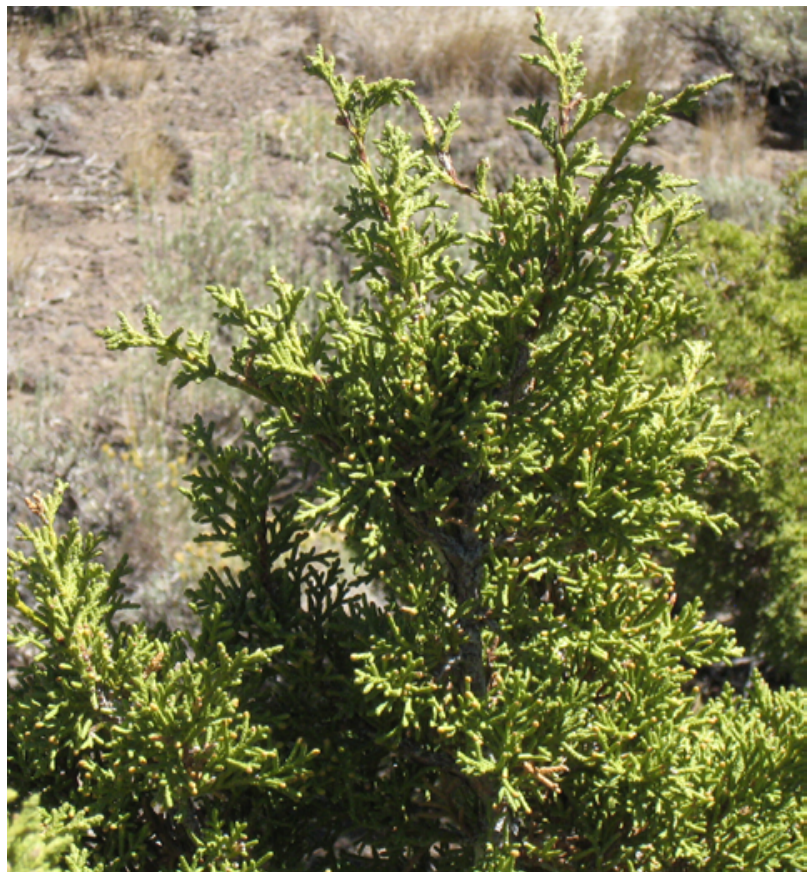

(b) Utah juniper leader growth in Phase II woodlands

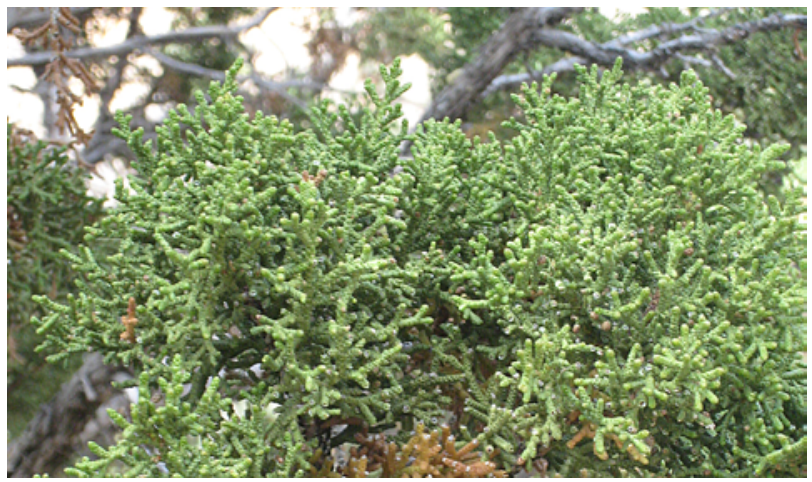

(c) Utah juniper leader growth in Phase III woodlands 
Figure 22. Continued.

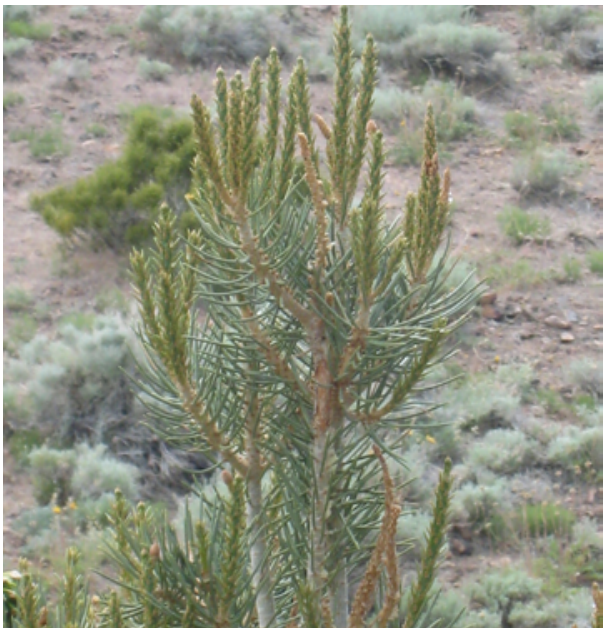

(d) Single leaf Piñon leader growth in Phase I woodlands

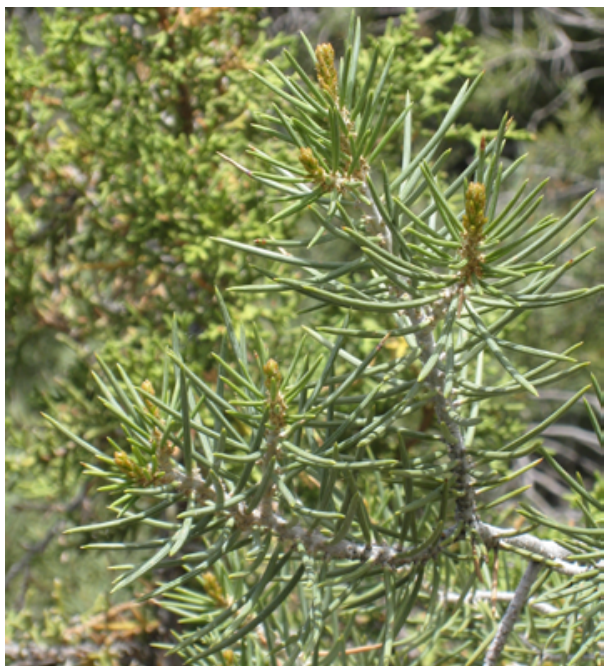

(e) Single leaf piñon leader growth in Phase III woodlands 
Figure 23. Three phases of woodland succession in piñonjuniper woodlands.

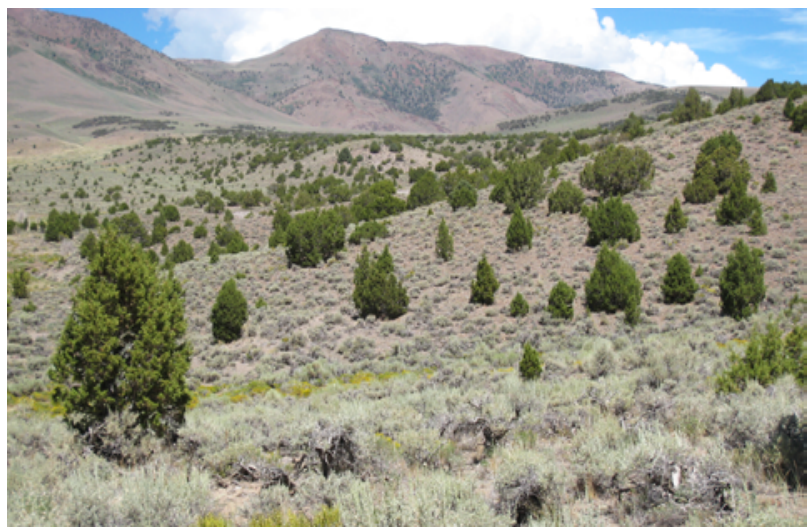

(a) Subordinate - Phase I

A subordinate piñon-juniper site with up-slope woodland expansion into mountain big sagebrush.

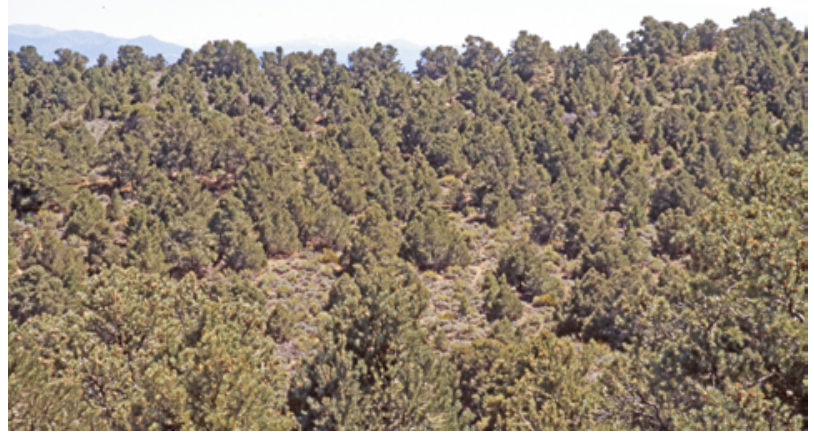

\section{(b) Co-Dominant - Phase II}

A co-dominate piñon-juniper, Wyoming big sagebrush site with moderately deep soils. 


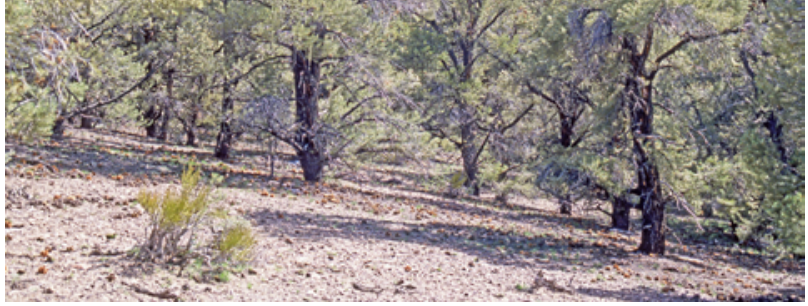

\section{(c) Dominant - Phase III}

A dominant piñon-juniper site with Wyoming big sagebrush and moderately deep soils.

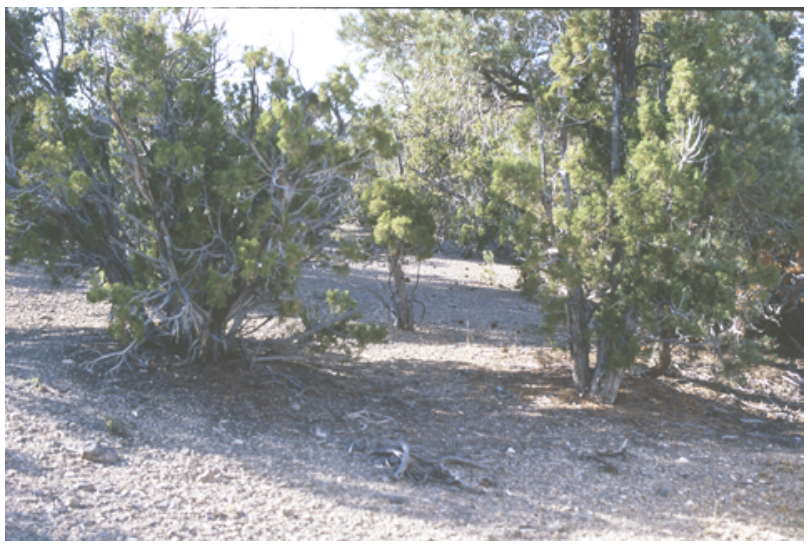

\section{(d) Dominant - Phase III}

A dominant piñon-juniper site with Wyoming big sagebrush on a south slope with a restrictive soil layer. 


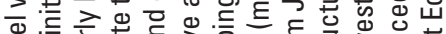

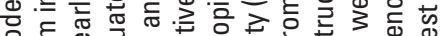
은

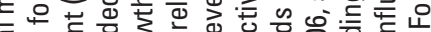

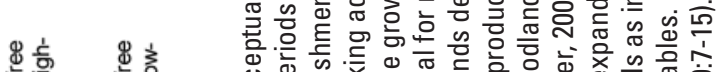

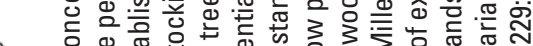

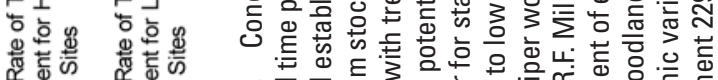

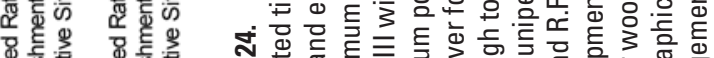

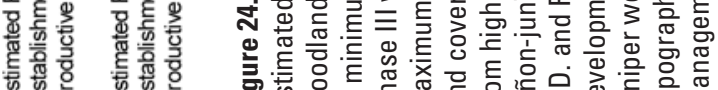

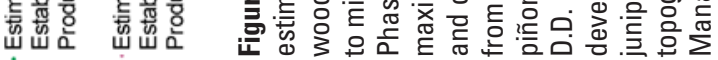

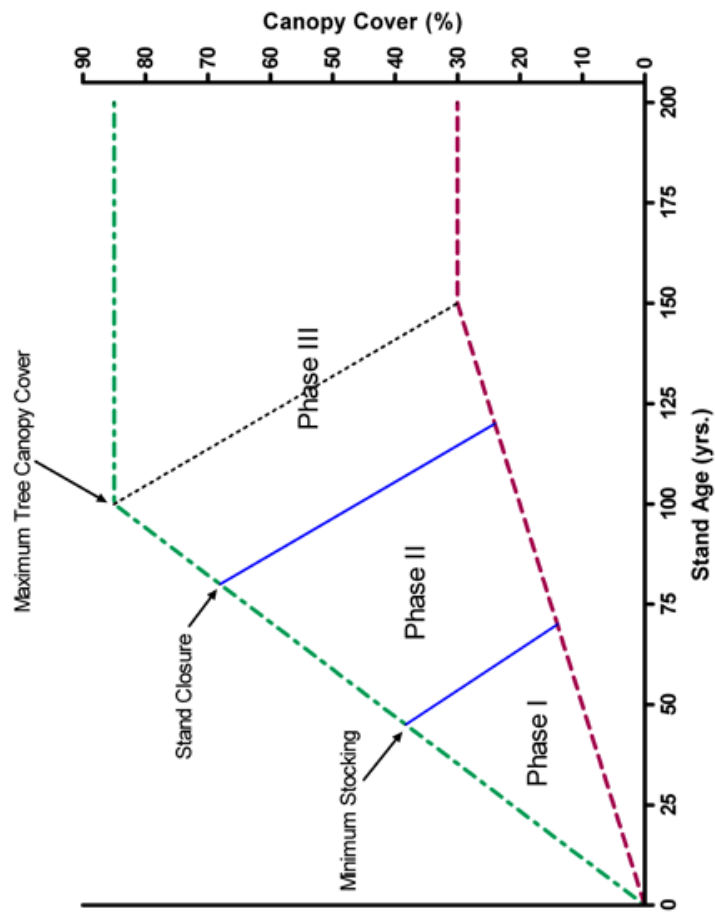

әэuepunq $\forall$ әәд әм!ाе|әу 

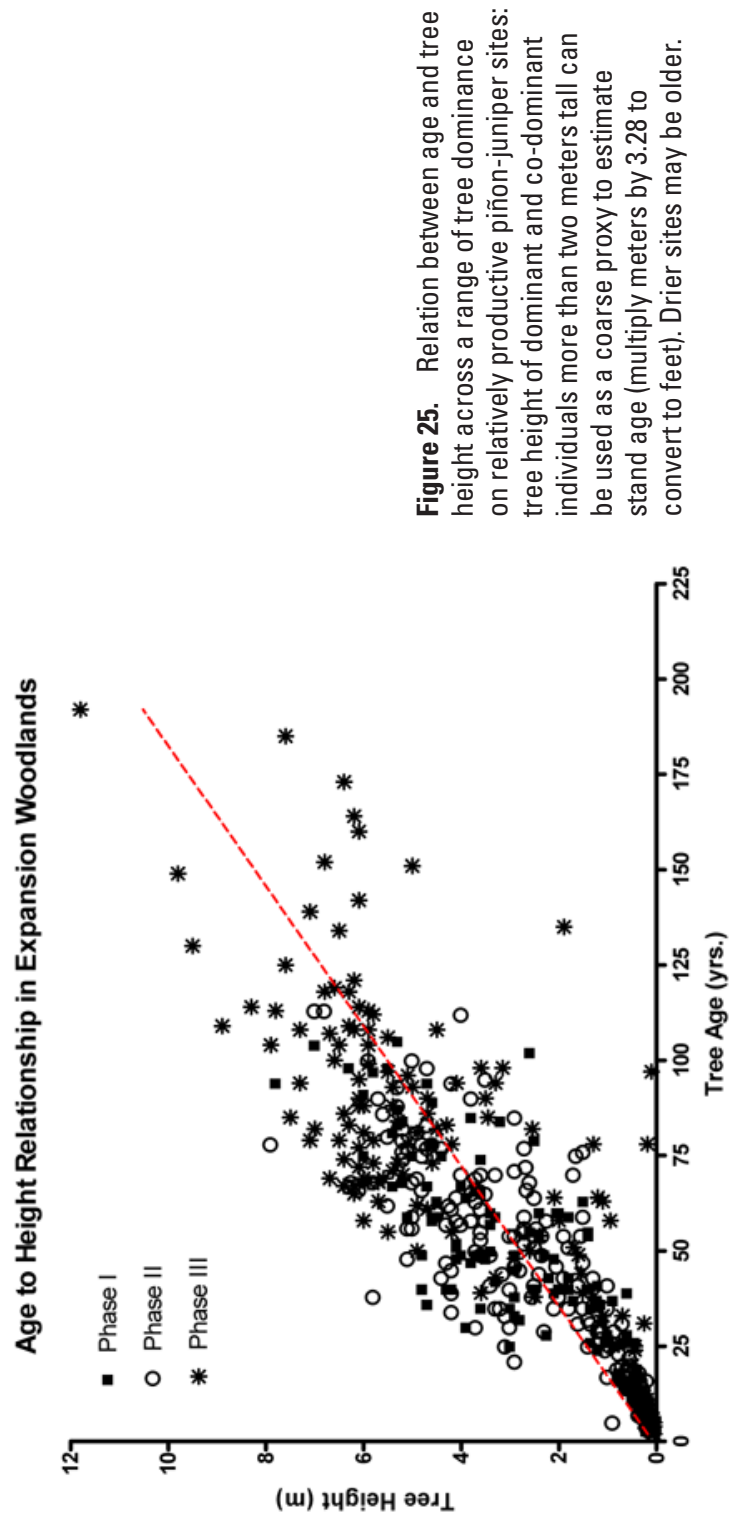


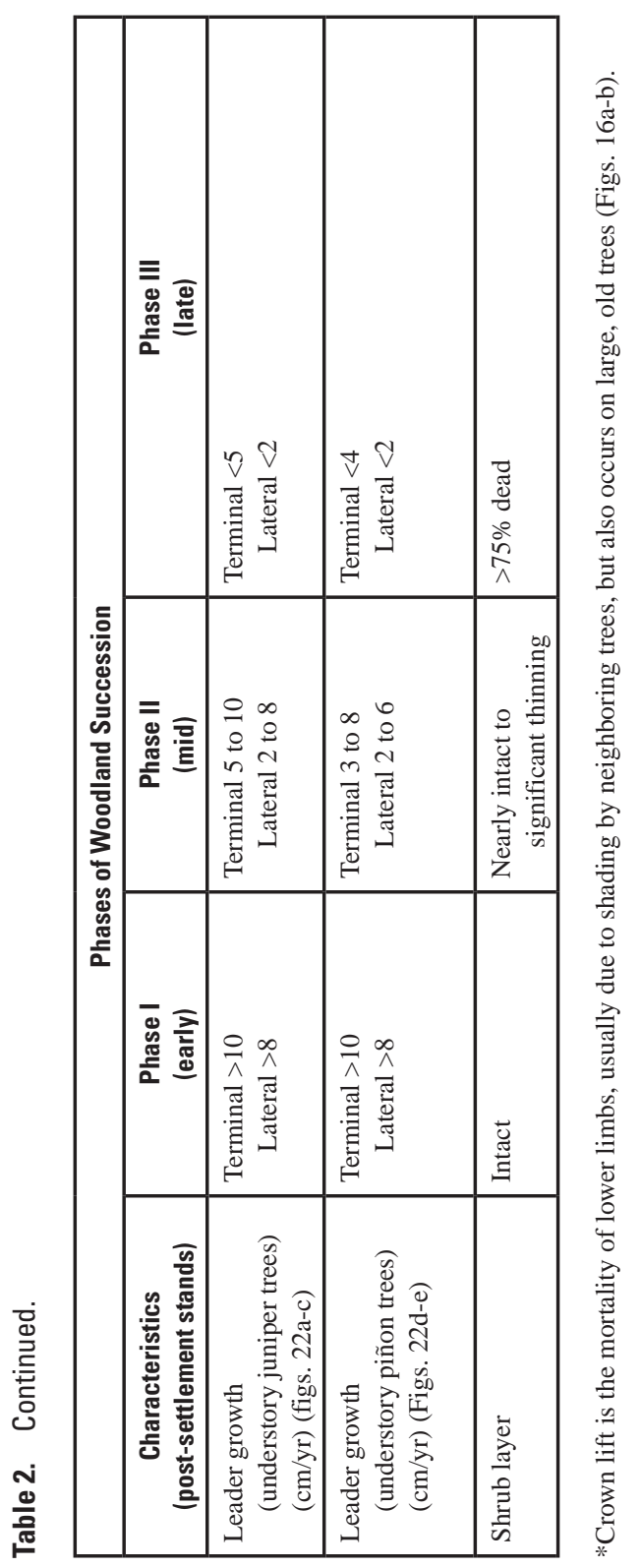

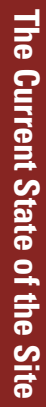
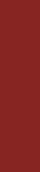
16. What is the current herbaceous understory composition?

- Is the density of tall perennial bunchgrasses adequate for restoration, or should the site be seeded?

- What are the desirable species, and how abundant are they?

- Is there evidence of reproductive effort for the desirable species?

- Are there young, deep-rooted perennial grasses?

- Are there threatened or endangered species on the site?

- Are invasive plant species present, or are seed sources near the site?

Pre-treatment understory composition, especially the relative abundance of native perennial grasses and forbs, is the primary determinant of the success or failure of efforts to restore plant communities by removing or thinning the trees. How does the current understory composition compare to the desired understory composition? Does pre-treatment understory composition, particularly for the herbaceous species, indicate that the species will survive and that the site will recover following a severe natural disturbance or proactive treatment?

Limited research suggests that if at least two deep-rooted perennial grasses (that is, needle grasses, bluebunch wheatgrass, Idaho fescue) per $1 \mathrm{~m}^{2}\left(10 \mathrm{ft}^{2}\right)$ persist on the site, recovery of understory vegetation after treatment is possible, although this is likely to vary with soil type, precipitation regime, and method of treatment. If perennial grasses and forbs are not present, or if existing plants are in such poor condition that they are unlikely to survive the treatment, seeding likely will be necessary. The presence of an invasive species seed source, like cheatgrass, also may increase the need to quickly seed the site (fig. 26). 

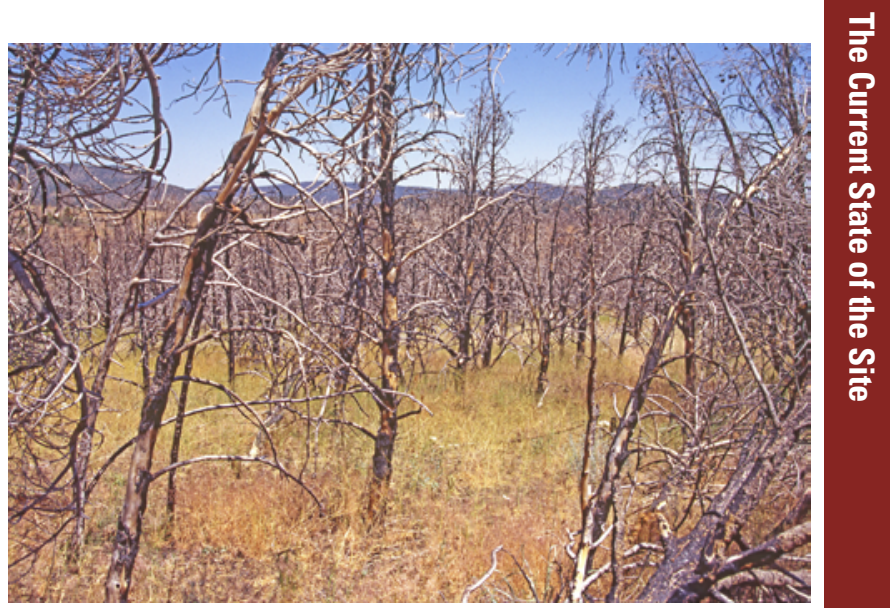

Figure 26. Third growing season after a high-severity fire in a high-productivity Phase III expansion piñon-juniper site. Crown cover in the pre-burn woodland exceeded $80 \%$. Loss of deep-rooted perennials on an otherwise productive site resulted in cheatgrass and tumble mustard dominance.

17. Is there recruitment of native perennial understory species?

- Are there different size sagebrush or bitterbrush indicating recruitment?

- Are there perennial grass and forb seedlings or small, young-looking bunches?

The presence of established seedlings and young plants indicates ongoing recruitment of species, while presence of healthy, mature, seed-producing plants indicates that the potential for seed production still persists on the site. If old, decadent, or dying plants are common and no signs of active reproduction/recruitment are found, species are likely on the decline and the site may require restoration. 
18. Are there invasive plant species on or adjacent to the site to be treated?

If undesirable plants, such as non-native weeds, are present on the site or present on adjacent sites, controlling their establishment and spread is likely to be an important part of the management plan. Weed invasion is more likely on the relatively warmer and drier sites, resulting from lower elevations and southerly aspects. Hot fires where woody vegetation is dense also will increase the potential of weed invasion (fig. 26). Several studies have shown that annual weeds can dramatically increase immediately after a tree-removal project or wildfire, but can decrease over a period of years if an adequate density of native perennials exists on the site prior to disturbance. A careful evaluation of expected desirable plant response based on the perennial grasses and forbs existing on the site prior to treatment, along with clear alternative plans in the event that native understory recovery does not occur as expected, will increase the likelihood of successful restoration.

19. What is the percentage of dead shrubs on the site, and what are the species?

As expansion woodlands increasingly dominate a sagebrush community, the number of suppressed and dead shrubs increases. A large number of dead shrubs indicates a site that was recently and rapidly dominated by trees (fig. 27). 


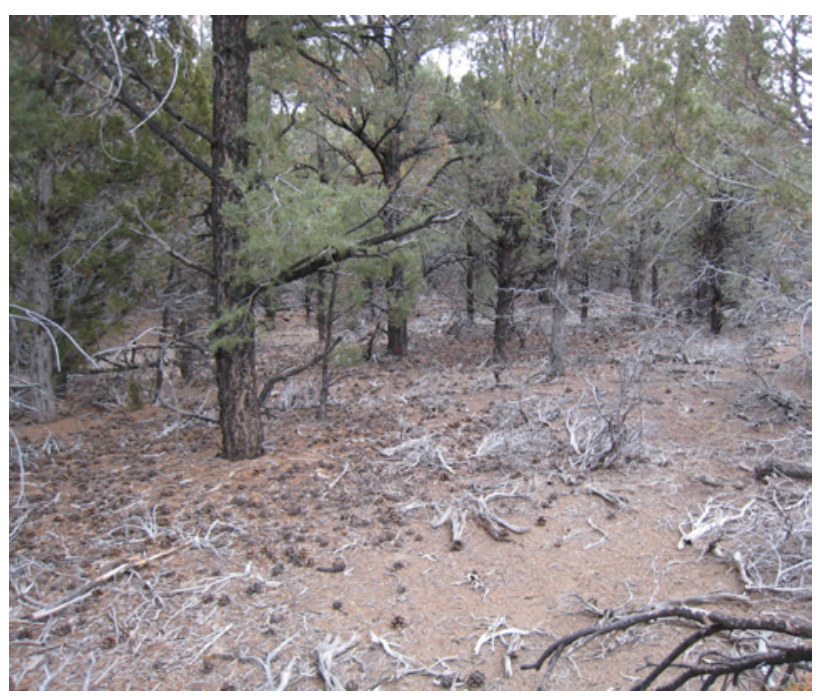

Figure 27. Rapid expansion and growth of piñon-juniper has led to bare ground and dead shrub skeletons. With heavy crown fuels, this Phase III woodland will burn under severe conditions, and introduced annual weeds will dominate the site following fire.

20. What are the fuel characteristics, and what types of fire will the site support?

-What type of prescribed fire will the site support, and will it burn under moderate conditions, or will it require more extreme conditions (fig. 28.)? 


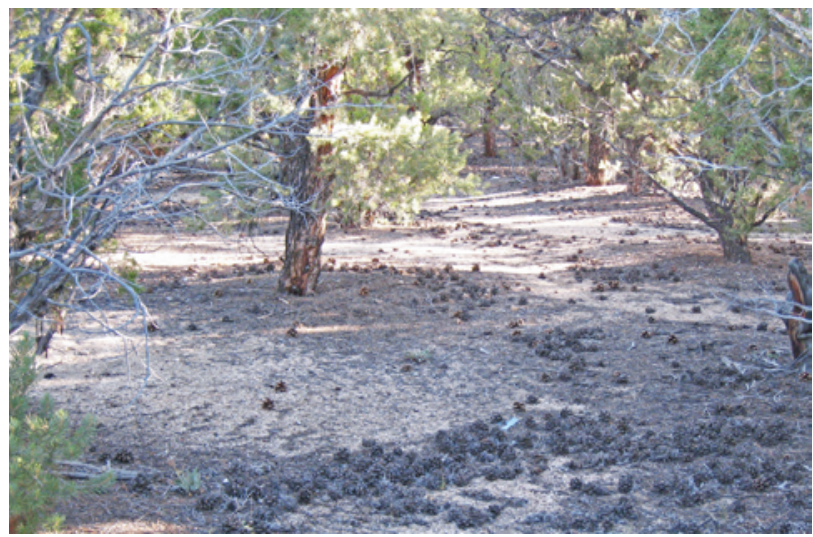

Figure 28. This site lacks both woody and herbaceous understory to carry a fire and adequate desirable herbaceous species for restoration. This Phase III woodland often burns under extreme conditions, with the outcome of introduced annual weeds dominating the site following fire (see fig. 26).

An assessment of fuel characteristics and their contribution to fire potential and behavior and an understanding of how natural processes (for example, water, nutrient, fire cycles) may be affected by treatment or no management action are necessary for selecting management treatments. Is herbaceous vegetation in the understory providing fine fuels? Does the amount of shrubs and small trees in the plant community provide sufficient ladder fuels to carry fire into tree canopies? Are the trees dominated by juniper, piñon, or a mix of the two? Does the site have a closed tree canopy? Are there openings in the canopy that may result in a mixedseverity fire with a mosaic fire pattern? Late Phase II, in addition to Phase III sites, often have sufficient crown cover to carry crown fires throughout the entire site with low humidity, high temperatures, and sufficient winds. The more piñon trees in the mix, the more potential for a crown fire. The bark of piñon can provide its own 
ladder fuels and carry the fire into the canopy if the fuels in the needle mat catch fire and fuel moistures are low. Branching at the base also facilitates fire reaching the crown.

Vegetation composition and fuels of the surrounding landscape landscape can directly affect fire risk and the ability to contain prescribed fire. Very high fuel loads adjacent to a site can greatly increase fire risk, and result in larger fires than planned.

21. Are there signs of erosion and overland flow? What is the current capacity of the site to capture, store, and safely release water (derived from interpreting indicators of rangeland health $\left.{ }^{2}\right)$ ? What is the incidence of highintensity summer thunderstorms?

Sites with large areas of bare ground, relatively fine-textured soils, steeper slopes, and potential for high-intensity thundershowers are susceptible to erosion. Runoff can move continuously through connected inter-canopy zones of bare ground, causing accelerated erosion (fig. 29). Soil in bare inter-canopy zones also is more susceptible to raindrop impact, soil crusting, decreased infiltration, and increased erosion due to lack of protection from vegetation. A thick overstory of trees also can reduce soil-water-capture and infiltration by limiting the amount of precipitation that reaches the

${ }^{2}$ Pellant, M., Shaver, P., Pyke, D., and Herrick. J., 2005, Interpreting indicators of rangeland health - version 4: Technical Reference 1734-6. U.S. Bureau of Land Management, National Science and Technology Center Denver, CO, 122 p. Available online at http://fresc.usgs.gov/ products/papers/1385_Pellant.pdf.

Swanson, S., Bruce, B., Cleary, R., Dragt, B., Brackley, G., Fults, G., Linebaugh, J., McCuin, G., Metscher, V., Perryman, B., Tueller, P., Weaver, D., and Wilson, D., 2006, Nevada Rangeland Monitoring Handbook, Second Edition: Educational Bulletin 06-03. Available online at http://www.unce.unr.edu/publications/files/ag/2006/eb0603. pdf. 


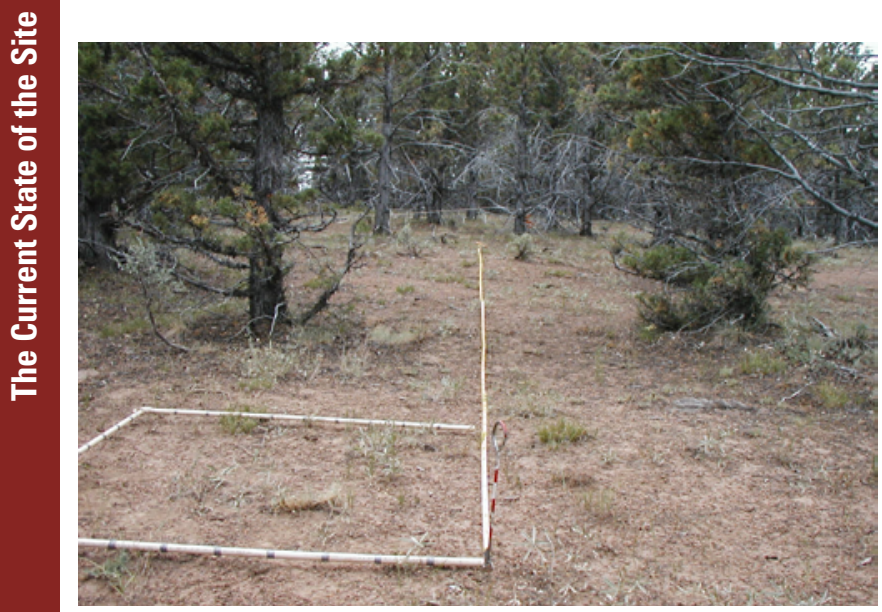

Figure 29. A Phase III Utah juniper site with large areas of bare ground potentially susceptible to accelerated runoff and erosion.

ground. Research indicates that when tree dominance is reduced and herbaceous cover is increased, runoff and soil erosion decrease on sites with relatively fine-textured soils. Leaving tree debris on the ground after mechanical treatments can intercept runoff and increase infiltration, increase soil moisture by reducing evapotranspiration and evaporative loss of soil water, and promote nutrient cycling. Signs of erosion may include rills, gullies, plant pedestals or terracettes, and water movement of large amounts of plant litter. Water flow patterns that show coalescing rills indicate high erosion potential (fig. 30). 


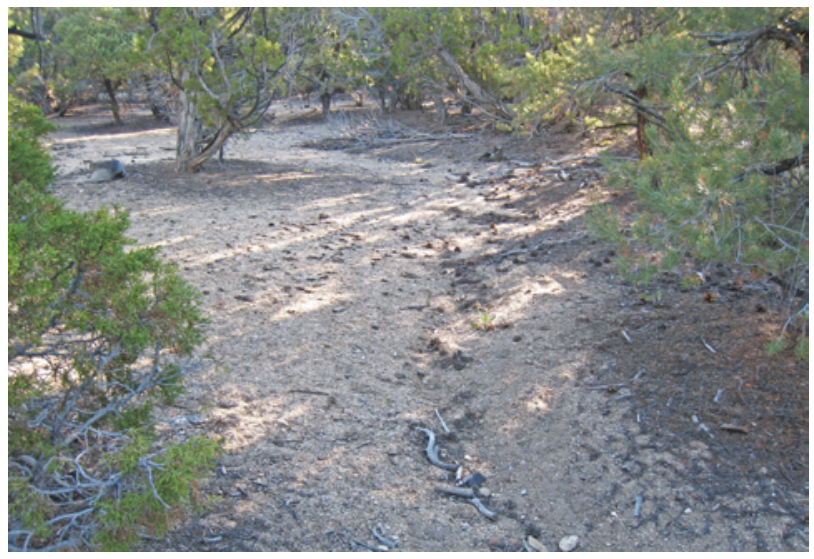

Figure 30. A piñon-juniper site with large, connected zones of bare ground and water flow patterns in the inter-canopy.

22. What is the current wildlife habitat suitability, and what species are involved? How will treatment affect wildlife species?

Habitat suitability will largely be determined by the composition and structure of vegetation at the community and landscape level. The spatial arrangement and connectedness of plant community patches are important attributes in determining habitat suitability. 
Increasing tree dominance at the community and landscape levels results in a decline in landscape and plant community diversity, which reduces wildlife abundance and diversity. Research has not identified any wildlife species that are obligates to closed (Phase III) woodlands. However, old-growth and open woodlands can provide important habitat especially for cavity nesters. Some habitat suitability conditions to consider when planning treatments are:

- Is the site in a transitional phase that will alter structure and composition, resulting in a change in habitat suitability?

- Juniper berries (female cones) can be an important winter food source for a variety of birds. Piñon nuts also are an important food source for many small mammal and bird species, particularly the Piñon Jay and Clark's Nutcracker. Maintaining a woodland component on sites where these species are present can be beneficial. However, as woodlands transition toward Phase III, juniper berry and pine nut production declines.

- Bird species diversity and richness are greatest in Phase I and early Phase II, when understory vegetation is still intact because these phases provide important structural diversity.

- Greater numbers of tree cavity-nesting birds are usually found in old-growth woodlands (fig. 31).

- Mule deer and elk use tree stands as winter cover. Dense stands with trees more than $5 \mathrm{ft}$ tall provide optimal thermal cover but minimal food resources if dense stands are present across large areas of the landscape.

- Decreased shrub cover due to woodland development and tree dominance results in decreased browse available for deer, elk, and other species.

- Decreases in grasses reduce seed production and seeds eaten by small mammals and birds. 


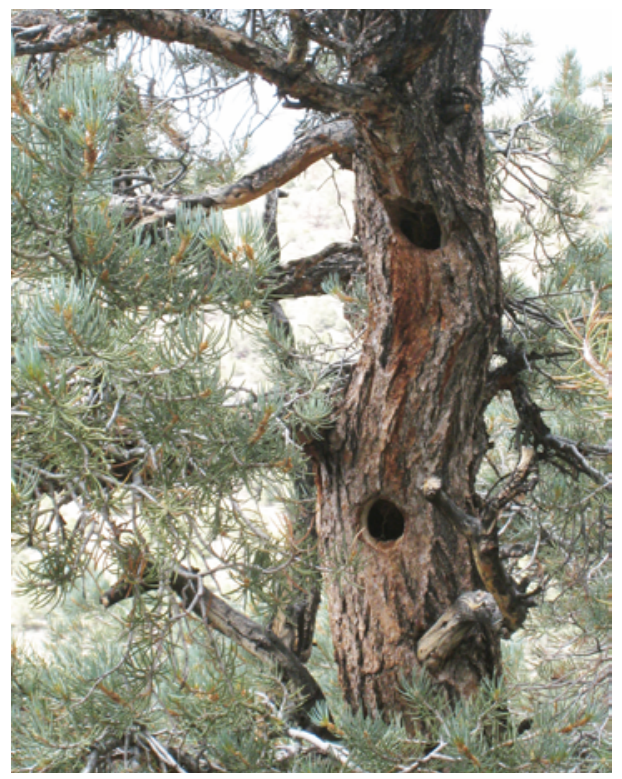

Figure 31. Tree cavity in the trunk of an oldgrowth singleleaf piñon. Old stands of trees have a relatively high density of cavity nesting birds.

23. Are there social or economic concerns and issues tied to the site?

Treatment of a site may not be feasible or practical due to ecological, economic, or sociological reasons. Treatment can be expensive, especially for Phase III woodlands, because of inputs needed to return the site to a desired condition, and achieving desired results can be difficult. Because Phase III woodlands are increasing in area, the potential for wildfires of increased intensity and severity is greater. Following wildfires, these sites will require expensive treatment to prevent dominance by cheatgrass and other exotic species (fig. 26). 
Conducting an economic evaluation of the options may assist a manager in considering the long-term environmental consequences. Not all benefits and costs involved with these treatments are quantifiable or have dollar values attached to them. This also applies to the long-term costs/benefits of not treating a site. In such cases, a social costs/benefit analysis can be used to identify both the quantifiable and non-quantifiable benefits and costs. Where dollar values cannot be determined, other economic principles may need to be determined to assist in allocating resources, such as treatment funds and labor.

Treating a stand in Phase I may make more economic sense than waiting until mid Phase II or beyond even though the apparent immediate benefits may be lower. Regardless of phase, seeding can be more risky on dry sites, where a high amount of erosion has occurred, where safe sites are not plentiful for seedling establishment, or where non-native invasive species are likely to quickly occupy the site. Tree removal on sites where any treatment is not likely to succeed may cause greater ecological damage (for example, increased bare ground, erosion and nutrient loss, increased weed invasion, and loss of wildlife habitat) than no management action. The potential increase in fire intensity and size with a continual increase in tree dominance also may need to be considered.

Social issues to consider include wildland-urban interface values, perceived ecological impacts of different treatments, concerns for sensitive wildlife and plant species, recreation, development, archeological sites, etc. 


\section{Part III: Landscape Considerations}

24. What are the spatial landscape characteristics

of the area to be treated with respect

to topography, patch ${ }^{3}$ size, edge, and connectedness?

Patch Size: Treatment patch size is especially important to consider in relation to use by wildlife and livestock. Is the treatment size large enough to provide suitable conditions for wildlife species of concern? Is the treatment area so small that post-treatment overuse/ overgrazing by domestic or wild herbivores will threaten the survival of newly established understory plants or aspen? Even with adequate forage in the area, the palatability of plants for several seasons after a fire will be higher than before, and burned patches will tend to attract wild and domestic herbivores. Is the patch size large enough to justify post-treatment management changes, such as no grazing for 1 or 2 years before or after the burn? If the treatment site is a relatively small area within a much larger pasture, resting the entire pasture from grazing may not be economically feasible or socially acceptable. Doing so may result in more ecological harm at other sites as grazing pressure is moved to those locations on either public or private land. Fencing a smaller treated area may be a viable option.

\footnotetext{
${ }^{3} \mathrm{~A}$ patch is defined here as an assemblage of plant species growing on a contiguous area forming a plant community with a defined boundary and possibly representing different successional stages within an ecological site.
} 
Edge: When needed, will treatment shape and layout create sufficient edge habitat that is valuable to wildlife? What treatment procedures will be used to result in sufficient edge habitat that is valuable to wildlife? How will the spatial distribution of edge influence seed rain from adjacent unburned sites onto the treated site? Feathering the edge can result in a more natural-looking appearance, as well as providing for more edge habitat.

Connectivity: Is the connectivity of various patches across the landscape important for wildlife species of concern? Patch topographic relationships and connectivity can influence wildlife movement, recruitment, predation, etc. Distance to similar patches or patches of concern and the vegetation conditions in between are part of a complex interaction of variables that influence connectivity for different wildlife species. Because they affect wildlife movement, recruitment, predation, etc., they need to be considered.

25. What is the composition of adjacent patches, what is their landscape distribution of vegetation patches, and what are their stages of woodland succession?

After considering how the site is connected to, or isolated from other patches and the distance to similar patches, will the treatment enhance wildlife habitat and watershed health? Do corridors exist between suitable habitat patches for wildlife movement? Does the composition of patches across the landscape provide diverse habitat for a variety of wildlife in all seasons? How will treatment affect biodiversity at the landscape level? 
26. What is the current variation in understory composition and in the recruitment of native understory species over the surrounding landscape?

The usefulness of treatment for a particular site can be influenced by the understory composition and recruitment present on the landscape around the site. Treatment of a site surrounded by Phase I and early Phase II woodlands, for example, can do more to enhance wildlife habitat than if it is surrounded by late Phase II or Phase III woodlands that may limit wildlife access and increase the risk of damage from adjacent crown fire.

\section{How do fuel characteristics of tree, shrub, and herbaceous layers vary over the surrounding landscape, what type of fires are they likely to support, and how might this influence the types of fire possible on the site?}

The fuel load characteristics on the landscape around the site of concern can, and in many circumstances will, override the fuel load characteristics of the site. This can result in types of fires that might not otherwise occur on the site, particularly wildfire.

28. Are there signs of erosion and overland flow from the surrounding landscape that suggest impacts to the site?

Watershed characteristics of the surrounding landscape, particularly up slope of the site, may have more to do with erosion occurring on the site than the conditions on the site. 
29. Will the conditions of the surrounding area influence the wildlife habitat suitability of the site, or affect the species involved?

Landscapes are composed of patches of different topographic sites, plant communities, and habitats. Management of landscapes rather than just individual stands includes consideration of patch composition, topographic and spatial arrangement, size, and connectivity. Consideration of which patches and how much to treat are important. Portions of these landscapes may provide key habitat for certain species (that is, sagebrush cover for sagebrush obligates or deer fawning). The initial removal of sagebrush as trees are removed may be necessary to maintain the long-term integrity of these important habitats. An alternative would be to treat a percentage of these key habitats, saving the remaining proportion for treatment at a later date when the treated areas have recovered. Maintaining a mosaic of patches of different successional stages also may be desirable for maximizing habitat diversity, reducing fuel continuity, increasing snow capture, etc.

\section{What are current uses, management activities, and social and economic concerns for the surrounding landscape that might affect the site?}

It is important to consider how a treatment will affect current use and management activities in the short and long term. If the immediate treatment negatively affects wildlife habitat or livestock grazing, how long will it take to realize benefits of treatment? Are there other areas available for these uses during the short term? If the treatment location is within a larger area that is being managed for other purposes such as fuels reduction, how will the treatment affect, and be affected by this management? 


\section{Part IV: Selecting Appropriate Management Actions and Treatments}

Woodland structure within and across successional phases, in addition to age, is largely determined by the type, frequency, and intensity of disturbance, especially wildfire. The most ideal management actions will be determined by considering the composition of all vegetation layers of the communities involved, economic feasibility, and social acceptability.

31. What are the factors that will influence selection of preventive, maintenance, or restoration treatments, including personnel available, grazing schedules, and wildfire risk?

1. Pre-treatment fuel composition, loading, and structure

- Tree sizes

- Number of trees per acre

- Dead plant material

- Herbaceous plant composition, size, and density

- Shrub composition, size, and density

2. Plant composition

- Abundance of desirable species

- Desirable fire-sensitive species (for example, sagebrush, bitterbrush)

- Invasive species

- Woodland phase

3. Ecological site, soils, and topography 
4. Species of concern (for example, sage grouse)

5. Objectives

6. Size of area to be treated

7. Legal liabilities and risks from proximity to other plant communities (for example, forest)

8. Cost and resources

9. Social acceptability

All nine factors also can be easily modified for use in the determination of post-fire management response.

32. What are treatment options, including mechanical, prescribed fire, cut and burn combinations, chemical applications, and seeding?

\section{Mechanical Treatments}

Mechanical treatments are often used to reduce tree dominance in Phases II and III woodlands. However, they make seedbed preparation and sowing difficult when the site requires revegetation. In general, the advantages of mechanical removal of trees include flexibility in timing of treatment application and the ability to precisely control treatment boundaries or targeted trees. For example, old-growth trees can be left as wildlife habitat. With mechanical treatments, the impact to understory vegetation is often minimal. Cut trees, slash, or chips also can be left on site to control erosion and provide safe sites for seedling establishment or to enhance wildlife habitat. Although Utah juniper is non-sprouting, the lower most limbs and green buds at the base must be removed to kill the tree (fig. 32). 


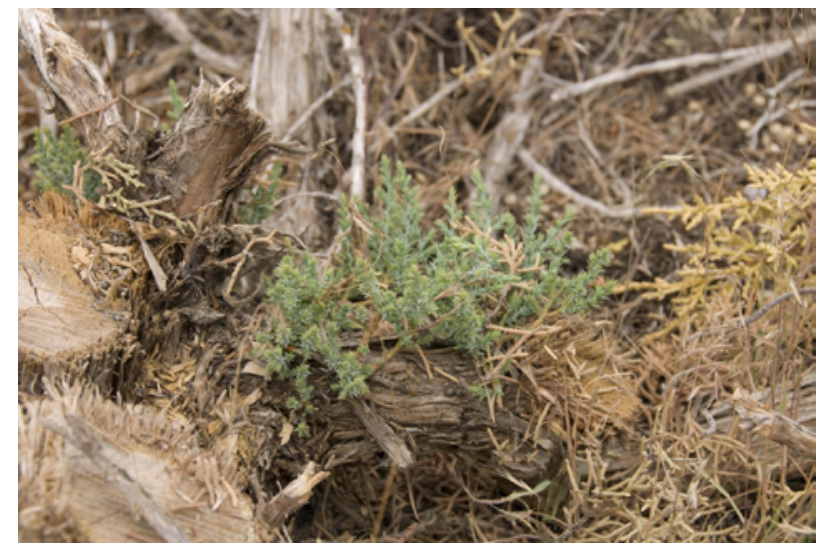

Figure 32. Example of juniper resprouting after chainsaw cutting left a lower limb.

Disadvantages are that mechanical methods often require follow-up treatment for small trees not initially removed, fuel loads can be increased by leaving cut trees/slash on the site, and treatment can be difficult to implement and costly when working in areas with rough terrain. Large amounts of slash in late Phase II and Phase III create a fire hazard for a minimum of 2 years and can limit the mobility of large herbivores (domestic and wild). Heavy slash, which may kill desirable plants by shading, will provide open sites for establishment of introduced species. It also may alter site nutrient relations.

Patience may be required in regards to treatment response when using mechanical treatments for restoration. A delayed understory response is common. Understory response in the first year after treatment is unpredictable, and it may take several years for understory plants to fully occupy the treated area. 
Heavy machinery: Heavy machinery can be used to reduce tree dominance, but these treatments tend to be expensive and should not be used when soils are excessively wet. Methods include using bulldozers to push trees over, chaining with bulldozers that pull anchor chains or steel cables to uproot trees, or the use of mechanical cutting and grinding devices such as the Bull Hog ${ }^{\mathrm{TM}}$ (fig. 33). Chaining can occur in one or two (opposite) directions, usually with seeding occurring between the two directions. When it fits project goals and is economically possible, removal of the downed trees can reduce fuel loads.

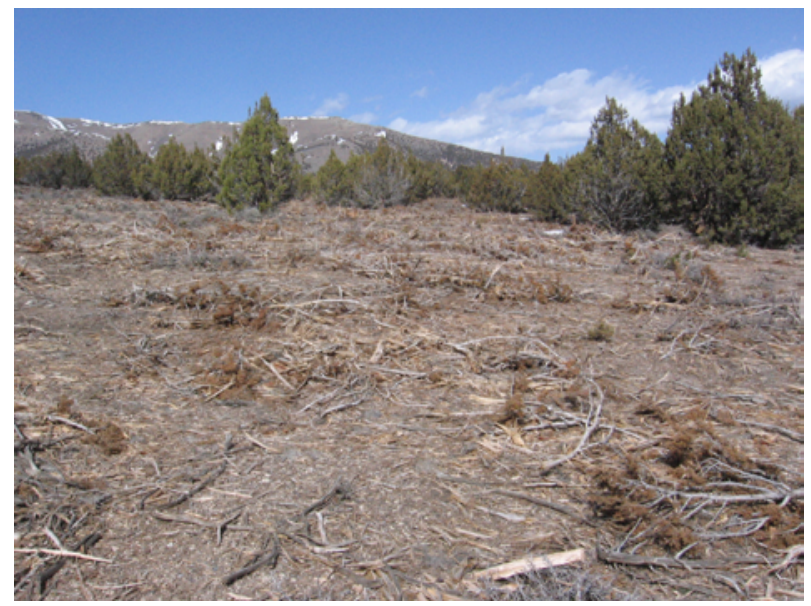

Figure 33. An example of tree mastication (bullhogging) on a juniper-dominated site in western Utah. 
Soil conditions, such as texture and moisture content, and machinery operation (for example, use of tight turns) should be evaluated, and factored into plans in order to minimize soil compaction and surface disturbance, such as avoiding times when soil-water content is high. Impacts on desirable understory vegetation also may be a concern with use of heavy machinery, but effects are often light to moderate with chaining. While, chaining has not been used in western juniper woodlands since the 1980s, it is still occasionally being used in piñon-juniper woodlands in Nevada, and in Utah after a fire. When not following a fire, chaining often requires a follow-up treatment, such as fire, to eliminate saplings and sustain the life of the treatment. Mastication treatments such as bullhogging are increasingly being used in Nevada and Utah. The shortand long-term ecological effects of these treatments are under study.

Feller bunchers cut and lay groups of 3-8 trees (depending on size) on the ground. Bundles can be left in place, burned, or chipped. However, little is known about the ecological effects of burning piles or leaving chips on site. Soil surface disturbance from feller bunchers is usually minimal on dry soils. Depending on the price being paid for chips and the distance they must be hauled, biomass utilization can significantly offset, if not pay for, the cost of tree removal. For more remote areas in which piñon-juniper woodlands are often found, transportation costs can make hauling the wood chips prohibitive.

\section{Chainsaw cutting: Chainsaw cutting selectively} kills trees with minimal soil disturbance (fig. 34). Costs increase when treating areas with steep terrain or areas where use of heavy machinery is not feasible. Cutting may be the only treatment option in areas of 
cultural resource concern. Expense of cutting treatments increases when limbs or slash are spread across the site, so this should only be done where post-treatment erosion is a risk. Smaller areas can often be more economically treated by opening them to the public for firewood cutting. This treatment will maintain and usually increase stand vigor of non-sprouting understory shrubs like sagebrush. However, cutting that leaves debris in place may increase the risk of fire.

Figure 34. Piñon-juniper chainsaw cutting in woodlands.

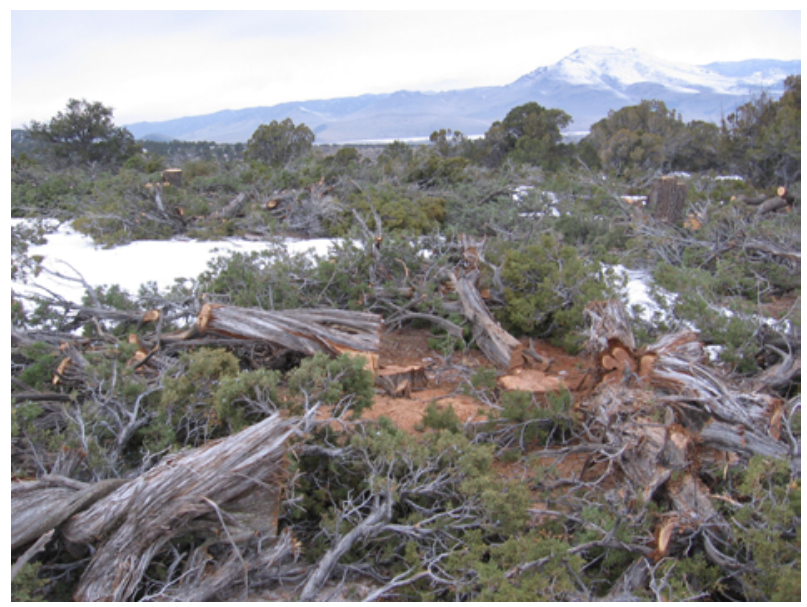

(a) On a juniper-dominated site in western Utah. 
Figure 34. Continued.

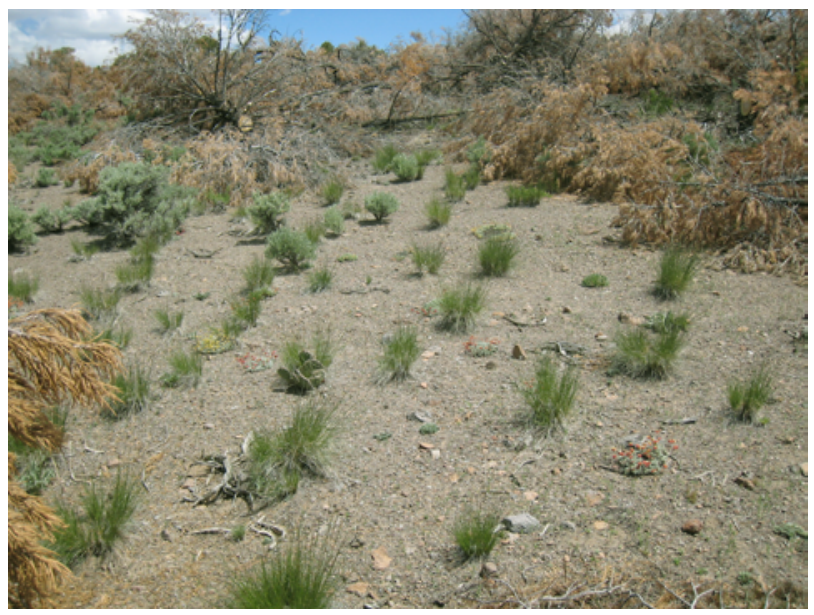

(c) Second growing season after chainsaw cutting on a piñonjuniper, Wyoming sagebrush site with Phase II woodlands. 
Figure 34. Continued.

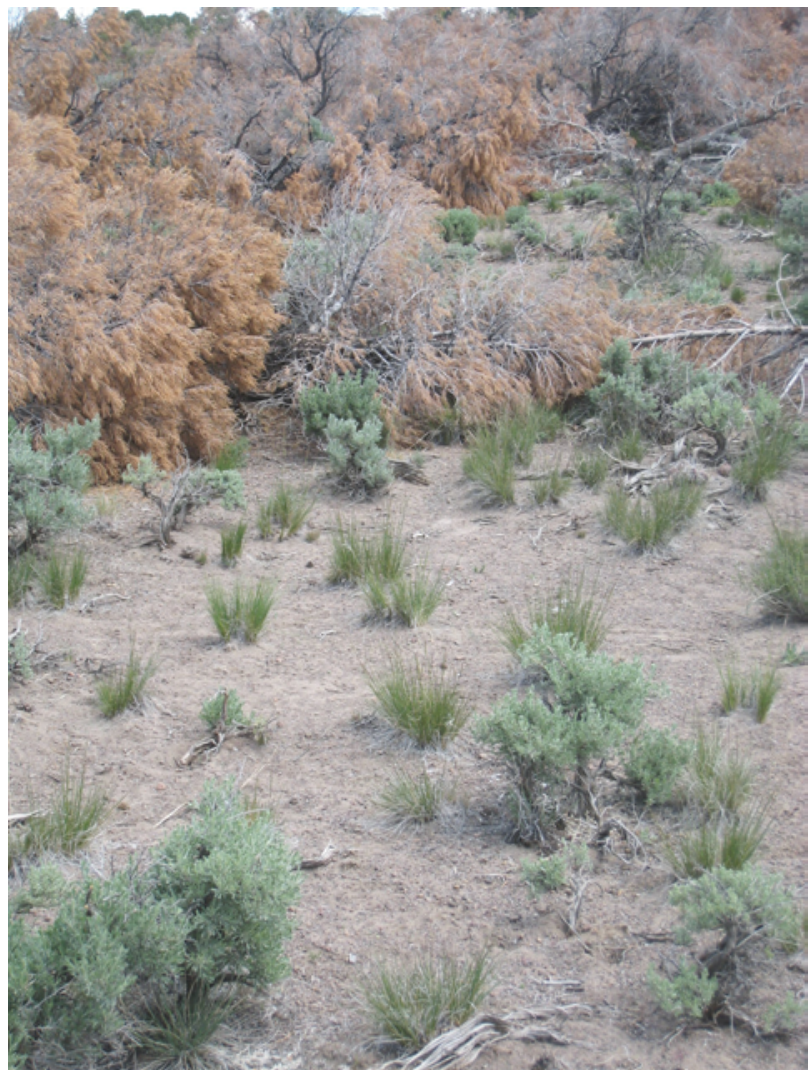

(d) Second growing season after chainsaw cutting on a piñon-juniper, Wyoming sagebrush site with early Phase III woodlands. 
Prescribed Fire: Prescribed fire is often the most economical way of treating larger landscape areas, particularly when woodlands are in Phase I or early Phase II. The primary factors that will influence postburn response to fire are:

- Plant community composition

- The presence or absence of perennial grasses, forbs, and seed pools prior to treatment

- Ecological site (site potential)

- Extent and patchiness of fire

- Climatic conditions before, during, and after the fire, which can increase stand vigor of non-sprouting shrubs like sagebrush. However, cutting that leaves debris in place may increase the risk of fire.

Prescribed fire treatments can produce desirable results on sites with woodlands in Phases I and II particularly when there is an abundance of perennial natives in the understory ( $>2$ desirable grasses $/ \mathrm{m}^{2}$ ) (figs. $35 a-b)$. On sites that are in late Phase II or Phase III and have a depleted understory, (1) fire may be difficult to carry through the stand as a result of limited ground and ladder fuels, (2) treatment may be more costly due to the need for higher inputs (see cutting and burning), and (3) site response less predictable with potential for success lower (for example, more annuals versus perennials in the response compared to treating sites in earlier states of woodland succession). Where tree dominance is high and woodlands are contiguous, crown fires can rapidly cover large areas. When piñon dominates, their bark can easily carry fire into the crown. When weeds, such as cheatgrass, are present on the site, risk of failure is increased, especially if the site is warm and dry, or where soils are shallow or fine-textured. Additional follow-up treatments to reduce undesirable species and seed herbaceous perennials can be beneficial. 


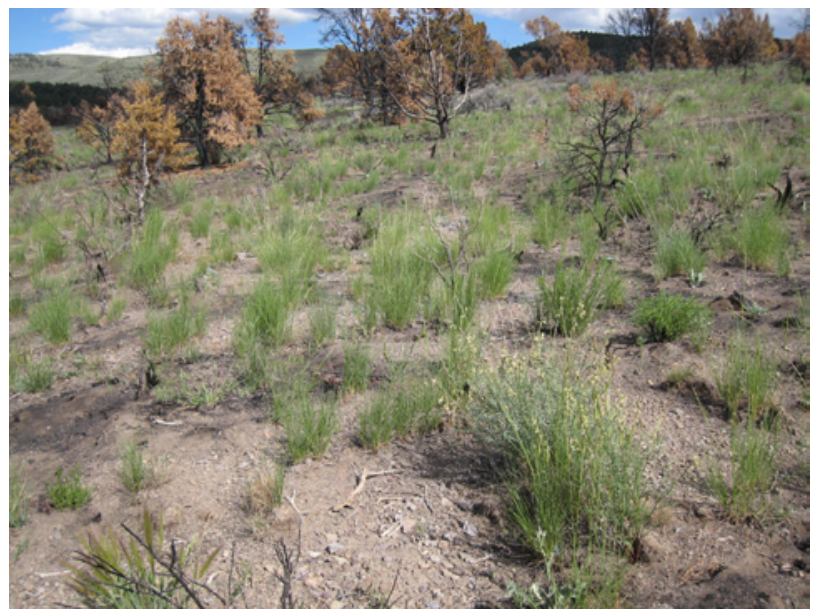

(a)

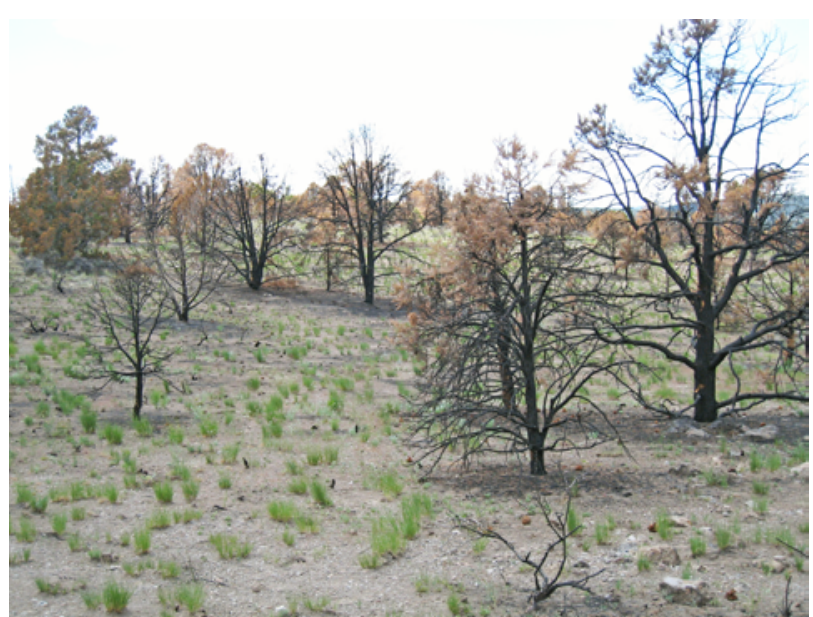

(b)

Figure 35. Understory responses 2 years after prescribed fire in Phases $(a) \mathrm{I},(b) \mathrm{II}$, and (c) III piñon-juniper dominated Wyoming big sagebrush communities in eastern Nevada. 


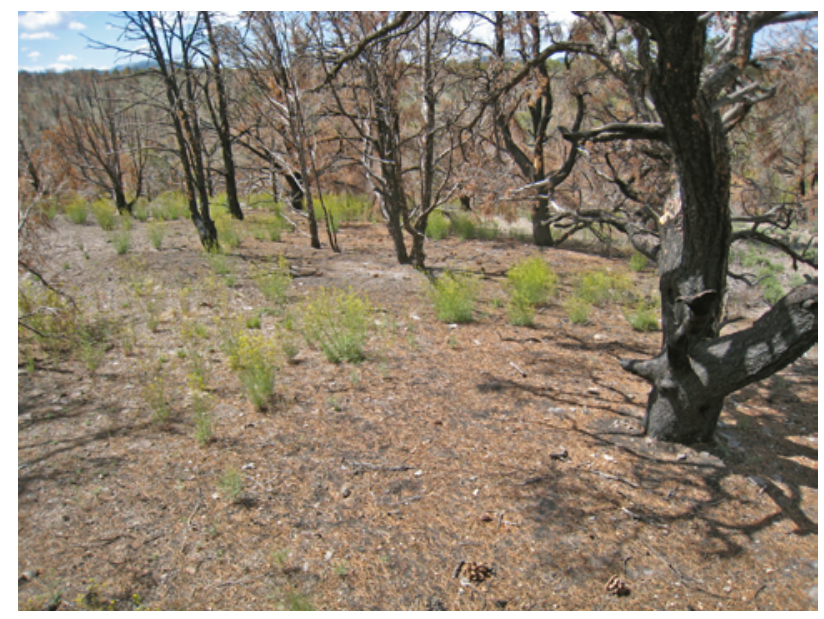

An initial response to either prescribed fire or wildfire includes decreased litter and woody vegetation and increased bare ground. How will these responses affect wildlife (that is, loss of the shrub layer), water runoff, and erosion in the short term? Mountain big sagebrush usually will recover to pre-burn levels within 25 to 35 years (varies with climate and seed source). Recovery in Wyoming big sagebrush areas is usually slower, but not always (fig. 36). Controlling the temperature and duration of prescribed fire, primarily where 100 and 1,000 hour fuels are heavy, is important for protection of the soil and understory vegetation. This may be achieved by fuel preparation so the fire treatment can be applied under more mild weather conditions. Sites that have a greater incidence of summer thunderstorms, finer textured soils, and steeper slopes have the highest soil erosion potential. Hydrophobicity can be a problem directly beneath the tree canopy resulting in limited seedling establishment and increased soil erosion. 


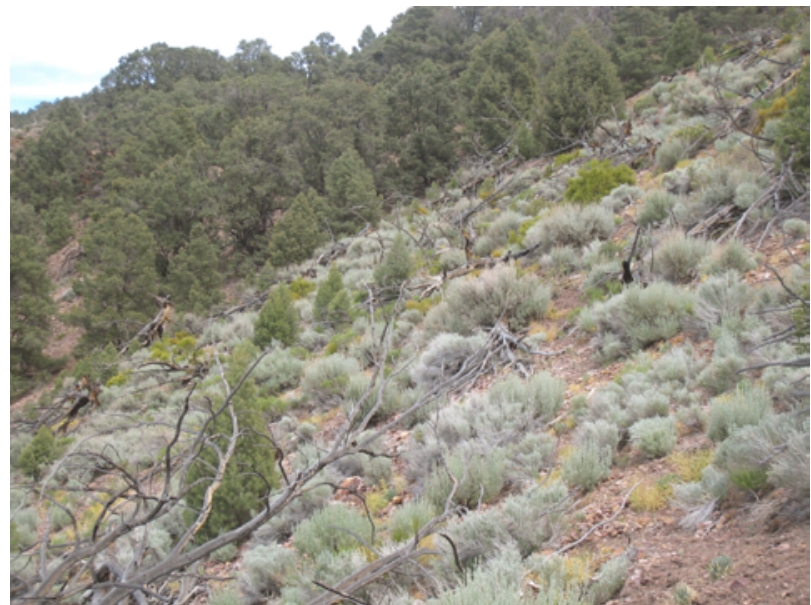

Figure 36. Thirty-five-year-old north-slope wildfire that burned through Phase III expansion piñon-juniper woodlands (still present in the background). It is now dominated by Wyoming big sagebrush with green rabbitbrush and green ephedra sub-dominant.

Burning in Aspen for Juniper and Piñon Removal

Due to high fuel-moisture conditions often found in aspen forests, prescribed fire can be difficult to implement. However, if suitable conditions (for example, fuel preparation - see 'Prescribed Fire' on p. 78) exist for fire, burning can produce desirable results. Protection from livestock and wildlife use may be necessary for aspen establishment after treatment. Research indicates this could take about 3 to 5 years to allow the terminal buds to grow above the browse line, but depends on site conditions and climate.

Cut and Burn Combinations: A combination of cutting and then burning is used to (1) increase ground fuels to carry fire or (2) remove tree slash created by cutting. This treatment combination is most often used in late Phase II and Phase III. Late summer or 
fall burning in Phase III can have severe effects on understory vegetation resulting in $>75 \%$ mortality. Late fall or winter burning (late Sept.-Mar.) has less-severe effects resulting in 20-50\% mortality of the remaining perennial grasses. Cut and burn treatment of Phase III stands is higher risk and more expensive than in Phases I and II. Cutting no more trees than necessary is recommended to keep the treatment as cost-effective as possible and to avoid building a fuel load that will result in a fire that is too hot. Other precautions noted earlier regarding understory vegetation, erosion, wildlife habitat, economic feasibility, and social acceptability on Phase III woodlands need to be considered.

Research on social acceptability of vegetation management in rangelands has found that citizens generally prefer prescribed fire as a treatment because it is perceived as more "natural" than other treatments. However, preference is maintained only insofar as smoke levels and risks of adjacent property damage are low; in locations near human habitation, mechanical treatment may be more acceptable to the public. All other things being equal, citizens are likely to prefer chainsaw cutting over the use of bulldozers. No published research has examined the relatively acceptability of cutting and grinding machines (that is, bullhogging) ${ }^{4}$.

\section{Chemical Treatments}

Because past chemical application on piñon and juniper, particularly western juniper, has met with poor or mixed results, only limited information is available to guide managers in using this method. The most important consideration for chemical treatment of woodlands is site selection. Chemical treatment should only be used on sites where the herbicide will work as intended (for example where the soil type, especially

\footnotetext{
${ }^{4}$ Brunson, M.W., and Shindler, B.A., 2004, Geographic variation in social acceptability of wildland fuels management in the western U.S.: Society and Natural Resources, v. 17, p. 661-678.
} 
high clay content, will not interfere with the chemical's performance) and the understory has potential to respond. Following herbicide treatment, standing trees may interfere with subsequent weed control and seeding of perennials. Social acceptability tends to be lower for chemical treatments than for any other restoration method.

Tebuthiuron and Picloram: Aerial application of pelleted tebuthiuron and picloram has been the most effective way of chemically controlling Utah juniper and piñon. Understory species tend to recover faster from picloram than tebuthiuron applications. Rates of up to $1.1 \mathrm{~kb}$ active ingredient/ha have been effective. Applicators should carefully follow label recommendations. High rates are more effective on more clayey or deep soils, while lower rates may be effective on shallow soils near ridge tops.

Other Chemicals: Velpar L. Pronone Power Pellets, Chopper and Arsenal treatments have been shown to be effective in northern California for juniper trees as tall as $6 \mathrm{ft}$. Chopper and Arsenal also have shown to be effective for treating cut juniper stumps with green limbs remaining below the cut.

\section{Seeding}

Success of seeding on treated sites to reduce tree dominance is greatly influenced by effective precipitation and soil texture. Because tree stumps typically remain following fire and downed trees or slash are present after mechanical treatments, broadcast seeding is often used. Methods that provide for good seed/soil contact should be used if possible. Seeding without some provision for seed coverage has only been successful for years or sites with high precipitation. Drill seeding is preferable in Phase I and low density Phase II stages or broadcast seeding followed by dragging a chain across the surface. 
Establishment of introduced and native grasses has been more consistently successful than that of native forbs or shrubs. Establishment of big sagebrush is inconsistent but may be enhanced by dropping seeds and pressing them into the soil surface with a packer wheel on a specialized drill or by aerial seeding on snow. Please see "restoring western ranges and wildlands" for detailed seeding recommendations (http://www.fs.fed.us/rm/pubs/ rmrs_gtr136.html) (figs. 37 and 38).

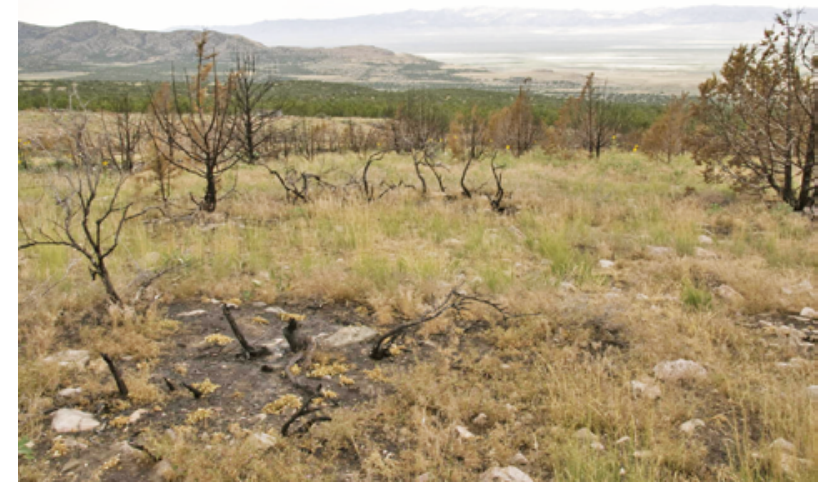

Figure 37. Moderate-severity fire (notice needles on trees) where $80 \%$ of the native species in the understory survived; no seeding is required. 


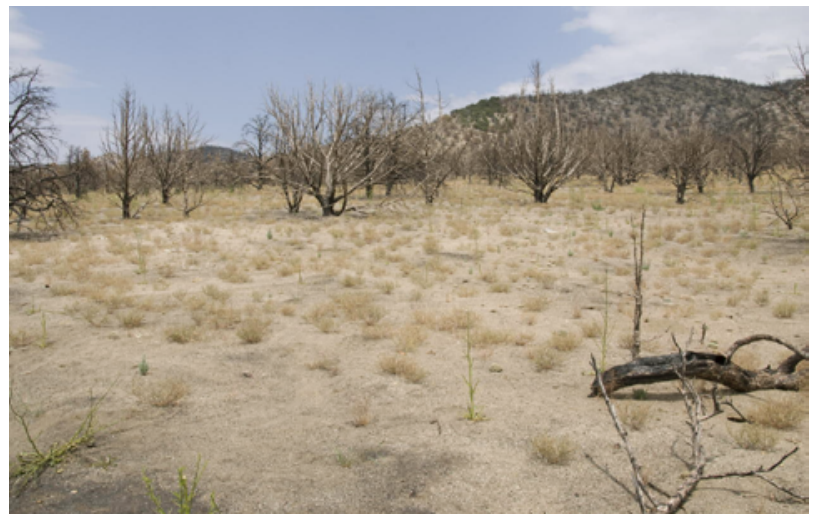

(a)

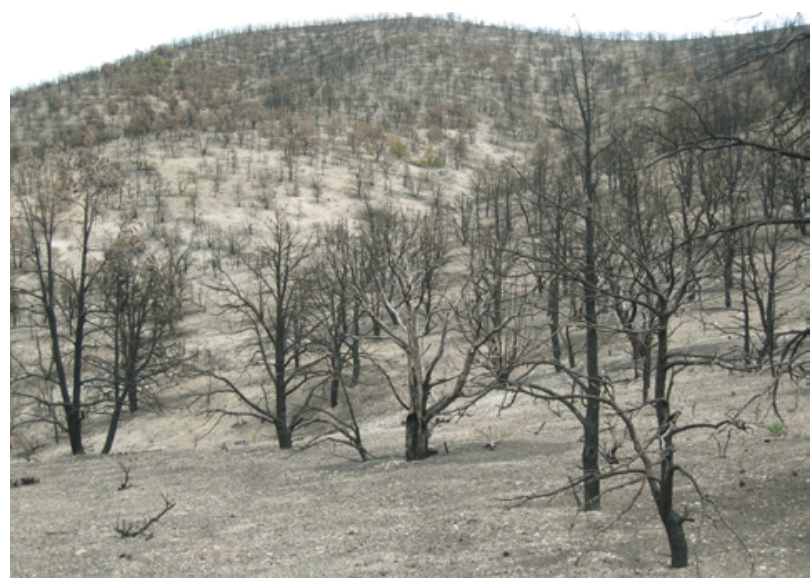

(b)

Figure 38. Examples of high-severity fire (notice no needles or bark remain on trees) where mortality of native herbaceous species was $>80 \%$. (a) One year after a western Utah fire, the site is dominated by introduced annual and biannual weeds; seeding required to reduce the spread of invasives. (b) One year after a fire in a dense Phase III expansion piñon-juniper site. Fire severity was such that only a few green plants are visible, most of them exotic annuals. Without seeding, the risk of dominance by exotic annuals is high. 
33. How will post-treatment management, including the need for maintenance on the site, and on the surrounding landscape affect site conditions and function?

Maintenance of desirable site conditions is most likely when post-treatment management remains adaptive and flexible, and when plans are continually reassessed. An optimal management approach considers short- and long-term successional responses and evaluates the benefits of maintenance of the site with follow-up treatments. A good post-treatment monitoring plan should be implemented. At a minimum, photographs should be taken at established points on a regular basis and cover of the dominant species should be assessed across the project area. More detailed monitoring may be necessary in areas where negative hydrologic responses or invasive species are potentially a problem. Changes in the condition of the landscape area adjacent to the treated site should also be noted.

How will treatment influence the distribution of livestock and wildlife use of the site? Rest from grazing following treatment will significantly improve the likelihood of success, especially if the understory is depleted. If it is not possible to keep animals out of the treated area, grazing impacts can be reduced by controlling placement of water and mineral supplements or grazing when herbaceous species are dormant in late summer and fall. This may also require the limitation or postponement of grazing in the surrounding area. After fire, 2 years of rest from grazing is a common practice, but plant response is often a better indicator of the actual amount of rest needed. In more arid areas or in areas in poor ecological condition prior to treatment, complete deferment and longer rest periods may be necessary. Grazing during the growing season in the first and second years following treatment has been shown to increase mortality and decrease leaf and seed production of desirable grasses. It also has been shown to increase 
the establishment and reproduction of invasive species like cheatgrass. Grazing after seed set in the first 2 years following treatment has been shown to have lesser effects on plant health. However, maximizing seed production and seedling establishment after treatment is important, and production of grass and forb seed is not likely to be significant until the second year post-fire. Usually, cutting and chemical applications minimally affect understory vegetation, but heavy equipment or highseverity fire may have greater impact. 


\section{Appendix 1: Field Assessment Form}

Site Name

Location

Date

\section{Ecological Site / Plant Association}
A. Diagnostic sagebrush species
B. Bitterbrush present? Y / N
C. Diagnostic perennial grass(es)
D. Old growth on the site (table 1)? Y / N
E. Large wood found on the site? Y / N
F. Plant association or PNV
G. Ecological Site

a. Soil Type

H. Historic fire return interval (key 2)

I. Soil erosion potential High Moderate Low

J. Species of concern

\section{Current State}
A. Dominant shrub recruitment. Y / N
B. Desirable shrub recruitment. $\mathrm{Y} / \mathrm{N}$

a. \% dead $<10 \% 11-25 \% 26-50 \%>50 \%$

C. Dominant grass(es)

a. $\geq 2$ desirable grasses $/ \mathrm{m}^{2}$ ? Y / N

D. Post-settlement trees present? Y / N; Phase I II III

E. Invasive species present? $\mathrm{Y} / \mathrm{N}$

F. Evidence of surface erosion (rills, sediment dams, pedestals, etc.)? Y / N

G. Current plant community 
H. Perceived problem

I. Habitat suitability for target species

Low Moderate High

a. If low or moderate, what is missing?

J. The site will burn With / Without pre-treatment.

K. Social concerns

L. Current uses

\section{Landscape considerations}
A. Size of area to be treated
B. How will treatment affect adjacent patches?
C. Treatment will fragment / link adjacent patches.
IV. Management Action

\section{Phase I and/or II (circle treatment recommendation)}
A. Cut
B. Burn
C. Seeding required $\mathrm{Y} / \mathrm{N}$
D. Other options

\section{Phases II and/or III (circle treatment recommendation)}
A. Partial cut and broadcast burn
B. Cut drop and leave
C. Cut drop and burn
D. Cut pile and burn
E. Seeding required $\mathrm{Y} / \mathrm{N}$
F. Other options

\section{Considerations}
A. Small trees may require follow-up
B. Weed potential, shrub layer, liability, structures, containment
C. Post treatment
D. Monitoring 


\section{Appendix 2: Species Codes}

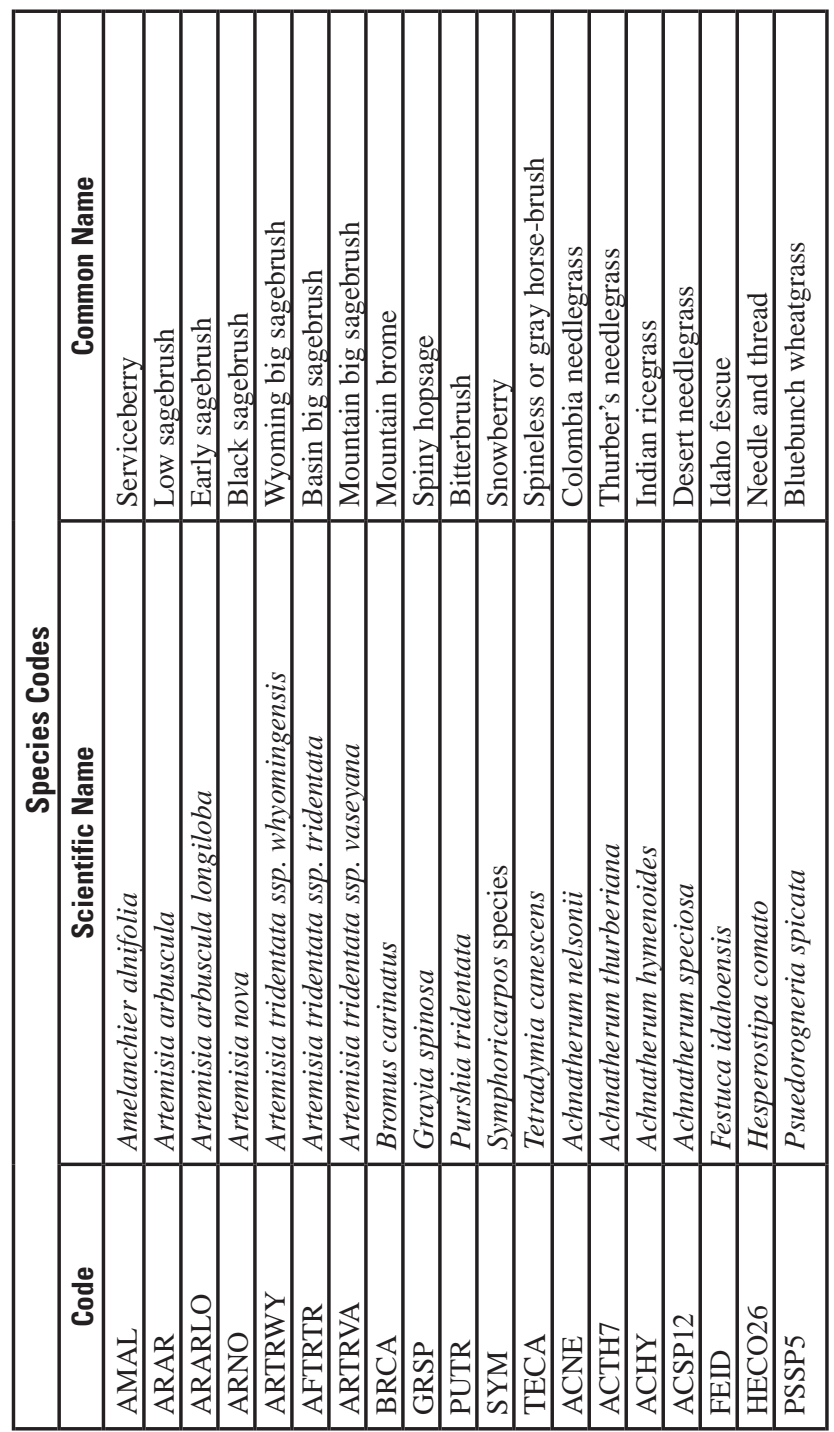




\section{Glossary of Terms}

Bare ground: exposed mineral soil that is susceptible to raindrop splash erosion. The size, distribution, and connectedness of bare ground are the most important contributors to site stability relative to site potential.

Cover type: see potential natural vegetation.

Ecological site: a type of land with specific physical characteristics that differs from other types of land in its ability to produce distinctive kinds and amounts of vegetation and its response to management. Apparently synonymous with ecological type used by USDA Forest Service, and Rangeland Ecological Site (http:// esis.sc.egov.usda.gov/Welcome/pgReportLocation. aspx?type=ESD).

Ecological function: referred to here as the actions or behavior of important processes such as hydrology, nutrient cycling, and energy capture.

\section{Fire Return Interval (FRI) (or fire free interval or} return fire interval): the number of years between two successive fires documented in a designated area (that is, the interval between two successive fire occurrences); the size of the area must be clearly specified. Variability in intervals is the meaningful reality of the disturbance regime on the site, not the mean (MFRI).

Fluted: pockets where the cambium layer folds in on itself forming deep grooves or bark pockets.

Fuel: all burnable material live and dead.

Functional goals: examples are watershed health, habitat for a defined set of species, etc., which are met by a desired set of conditions on the site often determined by vegetation composition and structure.

Gullies: channels that have been cut into the soil by moving water. 
Ladder fuel: material on or near the ground that will carry fire from the ground to the crown of trees (that is, sagebrush, bitterbrush, dead down wood and branches).

Management unit: an area of land defined by boundaries where a management strategy is to be applied. The land area may be composed of one or more ecological sites, and the entire area may or may not be treated.

\section{Mean Fire Return Interval (MFRI) (or mean fire}

free interval): arithmetic average of all fire intervals determined in a designated area during a designated time period; the size of the area and the time period must be specified. MFRI only provides the central tendency; variability in intervals is the meaningful reality of the disturbance regime on the site, not the mean (MFRI).

Post-settlement trees: trees establishing after 1860.

Potential natural vegetation (PNV): the vegetation that will persist under the pre-settlement disturbance regimes and climate. PNV is an expression of environmental factors such as topography, soils and climate across an area where cover type is a classification of existing vegetation. The existing cover type at any particular location and time may reflect a vegetation community anywhere along its successional pathway-from seral to climax.

Pre-settlement: trees establishing before 1860 (see oldgrowth).

Old-growth: a relative term that has been based on morphological characteristics, actual age, or general period of establishment (pre- and post-settlement, before or after 1860).

Rills: small, erosional rivulets that are generally linear and do not necessarily follow the microtopography that flow patterns do.

Savanna or savannah: grassland or shrub-steppe with widely scattered trees ( $<10 \%$ canopy cover). 
Soil/site stability: capacity of an area to limit redistribution and loss of soil resources including nutrients and organic matter by wind and water (Pellant, M., Shaver, P., Pyke, D.A., Herrick, J.E. 2005. Interpreting the indicators of rangeland health (version 4). BLM Technical Reference 1734-6. United States Department of the Interior, Bureau of Land Management National Science and Technology Center, Denver CO. 122 p.).

Species of concern: species that require special consideration in restoration. These include species that may increase following treatment (that is, noxious weeds) or species that are declining or appear to be in need of concentrated conservation actions, including State Endangered, State Threatened, State Sensitive, or State Candidate species.

Stocking: fully stocked site is one with enough trees that does or will eventually fully occupy a site (that is, at maturity, interspecific competition limits the expansion or addition of new leaf canopy). Stocking density varies across ecological sites and with tree size.

Water flow pattern: the path that water takes as it moves across the soil surface during overland flow. Evidence of water flow patterns include redistribution of litter, soil or gravel, or pedestalling of vegetation or stones.

Woodland: an area of smaller statured trees usually with canopy cover $>10 \%$; open $10-20 \%$, intermediate $20-40 \%$, dense $>40 \%$. 


\section{Abbreviations}

\begin{tabular}{ll}
\hline Abbreviation & Definition \\
\hline in. & inches \\
$\mathrm{ft}$ & feet/foot \\
$\mathrm{m}$ & meter(s) \\
$\mathrm{cm}$ & centimeter(s) \\
$\mathrm{mm}$ & millimeter(s) \\
$\mathrm{ha}$ & hectare \\
$\%$ & percent \\
$\mathrm{yr}(\mathrm{s})$ & year(s) \\
\hline
\end{tabular}


This page intentionally left blank. 
Publishing support provided by the U.S. Geological Survey Publishing Network, Tacoma Publishing Service Center

For more information concerning the research in this report, contact the

Communications and Information Management Program,

Forest and Rangeland Ecosystem Science Center,

U.S. Geological Survey, 777 NW 9th Street

Corvallis, Oregon 97330

fresc outreach@usgs.gov

http://fresc.usgs.gov 
옴

$\left.\right|_{0} ^{\infty}$

흥

름

틀

를

꿀

을

D

을

高

옹

틈

훙

จ

\%

(1)

g

릉

음

흘

คี

롱

를

또ำ

을

올

5

골

을

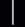

을

믈

$\vec{\omega}$ 